


\section{Effect van ruitzaai en drijfmestrijenbemesting op de stikstofbenutting van snijmaisteelt}

C.W. Klootwijk, H.A. van Schooten

Dit onderzoek is uitgevoerd in het kader van het publiek-private samenwerkingsprogramma "Ruwvoerproductie en Bodemmanagement" (www.ruwvoerenbodem.nl). 
Klootwijk, C.W., H.A. van Schooten, 2020. Effect van ruitzaai en drijfmestrijenbemesting op de stikstofbenutting van snijmaisteelt. Wageningen Livestock Research, Rapport 1256.

De doelstelling van dit project was om meer inzicht te verkrijgen in het meerjarig effect van een meer evenredige plantverdeling in de vorm van ruitzaai op de benutting van stikstof ten opzichte van de standaard rijafstand van $75 \mathrm{~cm}$ met en zonder drijfmestrijenbemesting. In dit onderzoek gaf een meer evenredige plantverdeling in de vorm van ruitzaai een licht hogere ds-opbrengst dan een standaard rijafstand van $75 \mathrm{~cm}$, maar dit leidde niet tot een significant hogere stikstofbenutting. De dsopbrengst en stikstofbenutting van drijfmestrijenbemesting waren in tegenstelling tot eerder uitgevoerd onderzoek wat lager vergeleken met standaard bouwlandinjectie.

The aim of this project was to gain more insight in the multiannual effect of a better plant distribution in the form of a triangle planting pattern on the nitrogen utilization compared to standard sowing in lanes with $75 \mathrm{~cm}$ distance with and without slurry injection in rows. This study shows that a more even plant distribution in the form of a triangle planting pattern showed a slightly higher DM-yield compared to standard sowing in lanes with $75 \mathrm{~cm}$ distance, but this did not result in a significantly higher $\mathrm{N}$ utilization. The DM-yield and the $\mathrm{N}$ utilization of slurry injection were, in contrast to previous studies, lower compared to standard slurry injection.

Dit rapport is gratis te downloaden van https://doi.org/10.18174/523002 of op www.wur.nl/environmental-research (ga naar 'Wageningen Livestock Research' in de grijze balk onderaan). Wageningen Livestock Research verstrekt geen gedrukte exemplaren van rapporten.

\section{(C) 2020 Wageningen Livestock Research}

Postbus 338, 6700 AH Wageningen, T 03174839 53, E info.livestockresearch@wur.nl, www.wur.nl/livestock-research. Wageningen Livestock Research is onderdeel van Wageningen University \& Research.

Wageningen Livestock Research aanvaardt geen aansprakelijkheid voor eventuele schade voortvloeiend uit het gebruik van de resultaten van dit onderzoek of de toepassing van de adviezen.

Alle rechten voorbehouden. Niets uit deze uitgave mag worden vermenigvuldigd en/of openbaar gemaakt worden door middel van druk, fotokopie, microfilm of op welke wijze dan ook zonder voorafgaande toestemming van de uitgever of auteur.

Wageningen Livestock Research is NEN-EN-ISO 9001:2015 gecertificeerd.

Op al onze onderzoeksopdrachten zijn de Algemene Voorwaarden van de Animal Sciences Group van toepassing. Deze zijn gedeponeerd bij de Arrondissementsrechtbank Zwolle.

Openbaar Wageningen Livestock Research Rapport 1256. 


\section{Inhoud}

$\begin{array}{ll}\text { Samenvatting } & \mathbf{5}\end{array}$

$\begin{array}{lll}1 & \text { Inleiding } & 7\end{array}$

$\begin{array}{llr}2 & \text { Materiaal en methode } & 8\end{array}$

2.1 Proefopzet $\quad 8$

$\begin{array}{lll}2.2 \text { Locatie } & 10\end{array}$

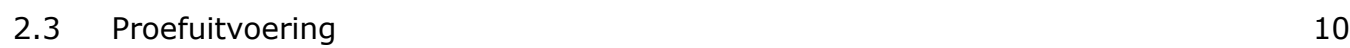

2.4 Bemesting $\quad 12$

2.5 Groeiomstandigheden 13

$\begin{array}{lll}2.6 & \text { Waarnemingen } & 15\end{array}$

2.6.1 Maisopbrengst 15

2.6.2 Gewasanalyse $\quad 15$

$\begin{array}{ll}2.6 .3 \text { Tussenoogst } & 15\end{array}$

2.6.4 Wortelbepalingen 16

2.6.5 Dichtheid bodem 17

$\begin{array}{lll}2.7 & \text { Statistische analyse } & 17\end{array}$

3

$\begin{array}{ll}\text { Resultaten } & 18\end{array}$

$\begin{array}{lll}3.1 & \text { Tussenoogst } & 18\end{array}$

3.2 Jaaropbrengsten en kwaliteit $\quad 18$

$\begin{array}{lll}3.3 & \text { Beworteling } & 21\end{array}$

$\begin{array}{lll}3.4 & \text { Dichtheid bodem } & 23\end{array}$

4 Discussie $r 25$

$\begin{array}{llr}5 & \text { Conclusies } & 28\end{array}$

$\begin{array}{lr}\text { Literatuur } & 29\end{array}$

$\begin{array}{lll}\text { Bijlage } 1 & \text { Resultaten per jaar } & 30\end{array}$ 



\section{Samenvatting}

Voor de teelt van snijmais wordt vanuit het mestbeleid de toegestane ruimte voor bemesting met dierlijke mest beperkt. Voor de praktijk betekent dit een extra stimulans om te zoeken naar teeltmethoden die de benutting van mest verbeteren. De doelstelling van dit project was daarom om meer inzicht te verkrijgen in het meerjarig effect van een meer evenredige plantverdeling in de vorm van ruitzaai op de benutting van stikstof ten opzichte van de standaard rijafstand van $75 \mathrm{~cm}$ met en zonder drijfmestrijenbemesting. Het uiteindelijke doel daarbij is een betere benutting van de aangewende stikstof uit dierlijke mest in de maisteelt.

In de periode 2016 t/m 2019 is een vierjarige veldproef uitgevoerd naar het effect van een meer evenredige plantverdeling in de vorm van ruitzaai op de stikstofbenutting ten opzichte van de standaard rijafstand van $75 \mathrm{~cm}$ met bouwlandinjectie (standaard praktijkmethode) en met drijfmestrijenbemesting. Tevens zijn de interacties van de drie teeltmethoden met twee $\mathrm{N}$ bemestingsniveaus (100 en $150 \mathrm{~kg} \mathrm{~N}$-werkzaam/ha), twee plantaantallen (80.000 en 110.000 planten/ha) en twee rastypen (open en dicht) onderzocht. De verschillende proefbehandelingen zijn elk jaar exact op dezelfde locatie aangelegd om eventuele meerjarige effecten mee te nemen.

Resultaten tonen dat de DS-opbrengst het hoogst was voor de teeltmethode ruitzaai, gevolgd door standaardzaai en dan drijfmestrijenbemesting (respectievelijk $21.317 \mathrm{~kg} / \mathrm{ha}, 20.865 \mathrm{~kg} / \mathrm{ha}$ en 20.338 $\mathrm{kg} / \mathrm{ha} ; \mathrm{P}<0.001$ ). De $\mathrm{N}$-opbrengst was hoger voor de teeltmethoden ruitzaai en standaardzaai vergeleken met drijfmestrijenbemesting (respectievelijk $225 \mathrm{~kg} / \mathrm{ha}, 222 \mathrm{~kg} / \mathrm{ha}$ en $216 \mathrm{~kg} / \mathrm{ha}$ $(\mathrm{P}=0.004)$. In lijn met de $\mathrm{N}$-opbrengst was de $\mathrm{N}$ recovery hoger voor de teeltmethoden ruitzaai en standaardzaai vergeleken met drijfmestrijenbemesting (respectievelijk 62\%, 59\% en 56\%; $\mathrm{P}=0.005$ ). De ontwikkeling van de mais van de behandeling met drijfmestrijenbemesting bleef in het 7-8e bladstadium al wat achter bij de beide andere teeltmethoden. Het hoge N-niveau met $150 \mathrm{~kg} / \mathrm{ha}$ had een hogere DS-opbrengst (respectievelijk $21.180 \mathrm{~kg} / \mathrm{ha}$ en $20.500 \mathrm{~kg} / \mathrm{ha} ; \mathrm{P}<0.001$ ) en een hogere $\mathrm{N}$ opbrengst (respectievelijk $230 \mathrm{~kg} / \mathrm{ha}$ en $212 \mathrm{~kg} / \mathrm{ha} ; \mathrm{P}<0.001$ ). De $\mathrm{N}$-recovery was zoals verwacht lager vergeleken met het lage $\mathrm{N}$-niveau (respectievelijk 55\% en $63 \% ; \mathrm{P}<0.001$ ). Gemiddeld over de vier proefjaren waren er geen interactie effecten van teeltmethode met $\mathrm{N}$-niveau, rastype en plantaantal wat betreft opbrengsten aan drogestof, VEM, en zetmeel en N-opname en N-recovery.

In dit onderzoek gaf een meer evenredige plantverdeling in de vorm van ruitzaai een licht hogers dsopbrengst dan een standaard rijafstand van $75 \mathrm{~cm}$, maar dit leidde niet tot een significant hogere stikstofbenutting. De ds-opbrengst en stikstofbenutting van drijfmestrijenbemesting waren in tegenstelling tot eerder uitgevoerd onderzoek wat lager vergeleken met standaard bouwlandinjectie. In de praktijk wordt bouwlandinjectie vaak uitgevoerd voor het ploegen terwijl in eerdere onderzoeken zowel bouwlandinjectie als drijfmestrijeninjectie veelal na het ploegen zijn uitgevoerd ten dienste van een robuuste vergelijking tussen deze twee methoden voor mestaanwending. Indicaties uit onderhavig onderzoek laten zien dat het mogelijke verdichtingseffect bij drijfmestrijenbemesting in de proef een rol kan spelen bij de verschillen van de resultaten vergeleken met eerder uitgevoerd onderzoek. 


\section{$1 \quad$ Inleiding}

Voor de teelt van snijmais wordt vanuit het mestbeleid de toegestane ruimte voor bemesting met dierlijke mest beperkt. Voor de praktijk betekent dit dat er een extra stimulans is om te zoeken naar teeltmethoden die de benutting van mest verbeteren. Eén van de methoden is het toepassen van drijfmestinjectie in de rij. Onderzoek heeft aangetoond dat deze methode de benutting van mineralen, met name $\mathrm{N}$ en $\mathrm{P}$, uit drijfmest verbetert (Van Dijk en Van der Schoot, 2001; Schröder, 1998; Schröder et al., 2015). Rijeninjectie met drijfmest kan in één werkgang met zaaien worden uitgevoerd of in een aparte werkgang. Een nadeel van de methode waarbij de drijfmestinjectie en zaaien in één werkgang wordt uitgevoerd is dat de zaaicapaciteit per tijdseenheid behoorlijk daalt. Tegenwoordig is het mogelijk met behulp van automatische besturing met RTK-GPS eerst de drijfmest in rijen op 75 $\mathrm{cm}$ afstand toe te dienen en op een later tijdstip de maïs boven en/of tussen de strookjes drijfmest te zaaien (Vermeulen et al., 2012.). Bij zowel de toepassing in één werkgang als in een aparte werkgang met zaaien heeft drijfmestrijenbemesting als nadeel dat de mest met een relatief zware machine na de hoofdgrondbewerking wordt aangewend. Dit brengt extra risico's met zich mee voor wat betreft structuurbederf, met name op relatief nattere en structuurgevoelige gronden. Daarnaast vraagt het een forse investering van de loonwerkers. Op basis van de positieve onderzoeksresultaten in het verleden is in het 6e actieprogramma betreffende de nitraatrichtlijn de maatregel opgenomen dat per 1 januari 2021 bij maisteelt op zand- en lössgronden alle verpompbare dierlijke mest als rijenbemesting moet worden toegediend. Vanuit de praktijk komt daarom regelmatig de vraag of i.p.v. "de mest naar de plant toe te brengen" met drijfmestrijenbemesting, "de plant naar de mest kan worden gebracht" door de maïsplanten regelmatiger te verdelen dan bij een rijafstand van $75 \mathrm{~cm}$. Gedacht wordt daarbij aan een halvering van de rijafstand. In het verleden zijn al ervaringen opgedaan met andere zaaiverbanden zoals nauwere rijafstand ( 50 of $37,5 \mathrm{~cm}$ ), stereozaai, deltazaai en vollevelds zaai (Van der Werf en Hoek,1988; Van der Schans et al., 1995; Van Dijk et al., 1995). Ten opzicht van een rijafstand van $75 \mathrm{~cm}$ leiden nauwere rijafstanden in het algemeen tot een betere ontwikkeling gedurende de jeugdfase. Bij de eindoogst waren de verschillen in opbrengst veelal klein. Genoemde onderzoeken met nauwere rijafstanden zijn inmiddels behoorlijk gedateerd en zijn uitgevoerd op gronden met een bemestingshistorie met veel ruimere normen dan de huidige bemestingsnormen. In meer recent oriënterend onderzoek in Duitsland met de zogenaamde ruitzaaimethode werden positieve effecten op de opbrengst gemeten van 5 tot 7\% (Demmel et al., 2002). Bij ruitzaai worden de maisplanten in driehoeksverband gezaaid, waarbij de afstanden tussen de planten in alle richtingen zoveel mogelijk gelijk is. Daarnaast zijn het afgelopen jaar in Nederland in de praktijk positieve ervaringen opgedaan met halvering van de rijafstand. Er is daarom behoefte aan meer informatie over de effecten van een meer evenredige plantverdeling ten opzichte van de standaard rijafstand van $75 \mathrm{~cm}$ en ten opzichte van drijfmestrijenbemesting.

De doelstelling van dit project is om meer inzicht te verkrijgen in het meerjarig effect van een meer evenredige plantverdeling in de vorm van ruitzaai op de benutting van stikstof ten opzichte van de standaard rijafstand van $75 \mathrm{~cm}$ met en zonder drijfmestrijenbemesting. Het uiteindelijke doel daarbij is een betere benutting van de aangewende stikstof in de maisteelt, vooral in de fase dat het wortelstelsel van de maisplant nog klein is. 


\section{Materiaal en methode}

\section{1}

\section{Proefopzet}

Van maart 2016 tot december 2019 is in een veldproef onderzoek gedaan naar het effect van een meer evenredige plantverdeling in de vorm van ruitzaai op de stikstofbenutting ten opzichte van de standaard rijafstand van $75 \mathrm{~cm}$ met bouwlandinjectie en met drijfmestrijenbemesting. Tevens zijn de interacties van de drie teeltmethoden met $\mathrm{N}$-bemestingsniveau, plantaantal en rastype onderzocht. In het verleden is gebleken dat het effect van drijfmestrijenbemesting groter werd naarmate het $\mathrm{N}$ bemestingsniveau lager was. Daarom is er gekozen voor een $\mathrm{N}$-bemestingsniveau in de buurt van het advies van $150 \mathrm{~kg} \mathrm{~N}$-werkzaam per ha en een lagere $\mathrm{N}$-bemestingsniveau van $100 \mathrm{~kg} \mathrm{~N}$-werkzaam per ha. In het onderzoek zijn twee verschillende plantaantallen meegenomen omdat een hoger plantaantal bij ruitzaai mogelijk een groter positief effect op de opbrengst heeft dan bij standaard $75 \mathrm{~cm}$. Het geadviseerde plantaantal bij normale zaai is 90.000 tot 100.000 planten/ha. Tenslotte zijn twee rastypen met een verschillende bladstand meegenomen in het onderzoek omdat deze mogelijk verschillend reageren op een meer regelmatige plantverdeling. Een rastype met een steile bladstand kan wat betreft lichtonderschepping mogelijk meer profiteren van een regelmatiger plantverdeling dan een rastype met een breed uitstaande bladstand omdat de bladeren van de buurplanten elkaar minder snel overlappen. De proefbehandelingen zijn elk jaar steeds exact op dezelfde locatie aangelegd om eventuele meerjarige effecten mee te nemen.

In een volledig gewarde blokkenproef werden de volgende factoren onderzocht in viervoud:

1. Teeltmethoden:

a. $75 \mathrm{~cm}$ rijafstand (standaard) met volvelds bouwlandinjectie (standaard)

b. Ruitzaai bij $37,5 \mathrm{~cm}$ rijafstand met volvelds bouwlandinjectie (ruitzaai)

c. $75 \mathrm{~cm}$ rijafstand (standaard) met rijeninjectie (drijfmestrijenbemesting)

2. N-niveaus

a. $100 \mathrm{~kg} \mathrm{~N}$-werkzaam per ha (30 $\mathrm{m}^{3}$ runderdrijfmest $+15 \mathrm{~kg}$ kunstmest- $\mathrm{N}$ per ha)

b. $150 \mathrm{~kg} \mathrm{~N}$-werkzaam per ha (30 $\mathrm{m}^{3}$ runderdrijfmest $+70 \mathrm{~kg}$ kunstmest-N per ha)

3. Rastypen

a. Dicht rastype (relatief breed uitstaande bladstand)

b. Open rastype (relatief steile bladstand)

4. Plantaantal

a. 80.000 planten/ha

b. 110.000 planten/ha

De combinatie van factoren leidden tot 24 behandelingen. Daarnaast werden veldjes zonder $\mathrm{N}-$ bemesting aangelegd bij $75 \mathrm{~cm}$ rijafstand en ruitzaai, om de apparent N-recovery te kunnen berekenen. Daarmee komt het totaal aantal behandelingen op 26. Figuur 1 geeft een overzicht van de toewijzing van de behandelingen aan de plots. De bruto oppervlakte van de veldjes was $6 \times 12=72$ $\mathrm{m}^{2}$ en de netto oppervlakte was $3 \times 10,2=30,6 \mathrm{~m}^{2}$. De teeltmethoden zullen in de rest van het rapport worden beschreven als 'standaard', 'ruitzaai' en 'drijfmestrijenbemesting'. 


\begin{tabular}{|c|c|c|c|c|c|c|c|c|c|}
\hline \multirow{2}{*}{\begin{tabular}{|c}
1 \\
bruto
\end{tabular}} & \multirow{2}{*}{\begin{tabular}{|l}
$\|$ \\
bruto
\end{tabular}} & \multirow{2}{*}{\begin{tabular}{|c} 
III \\
bruto
\end{tabular}} & \multirow{2}{*}{\begin{tabular}{|l} 
IV \\
bruto
\end{tabular}} & \multicolumn{2}{|c|}{\begin{tabular}{l|l}
\multicolumn{2}{l|}{} \\
$\mathrm{Nr}$ & Toltmothoden
\end{tabular}} & \\
\hline & & & & $\mathbf{N r}$ & Teeltmethoden & $\begin{array}{l}\mathrm{N}- \\
\text { niveau }\end{array}$ & $\begin{array}{l}\text { Plant } \\
\text { aantal }\end{array}$ & Rastype & Code \\
\hline \multirow{2}{*}{$26^{\circ}$} & \multirow{2}{*}{$52^{B}$} & \multirow[b]{2}{*}{$78^{B}$} & \multirow[b]{2}{*}{$104^{\top}$} & 1 & $75 \mathrm{~cm}$ onbemest & - & 11 & dicht & A \\
\hline & & & & 2 & Standaard & 100 & 8 & open & $\mathrm{B}$ \\
\hline \multirow{2}{*}{$25^{L}$} & \multirow{2}{*}{${ }_{51}{ }^{\mathrm{D}}$} & \multirow{2}{*}{$77^{w}$} & \multirow{2}{*}{${ }_{103} \mathrm{x}$} & 3 & Standaard & 100 & 8 & dicht & $\mathrm{C}$ \\
\hline & & & & 4 & Standaard & 100 & 11 & open & $\mathrm{D}$ \\
\hline $24^{F}$ & ${ }_{50} \mathrm{H}$ & $76^{u}$ & $102^{\circ}$ & 5 & Standaard & 100 & 11 & dicht & $E$ \\
\hline \multirow{2}{*}{$23^{A}$} & \multirow[b]{2}{*}{49} & \multirow[t]{2}{*}{ F } & \multirow{2}{*}{${ }_{101}{ }^{Q}$} & 6 & Standaard & 150 & 8 & open & $\mathrm{F}$ \\
\hline & & & & 7 & Standaard & 150 & 8 & dicht & $\mathrm{G}$ \\
\hline 22 & \multirow{2}{*}{$48^{Q}$} & ${ }_{74}^{R}$ & ${ }_{100}^{E}$ & 8 & Standaard & 150 & 11 & open & $\mathrm{H}$ \\
\hline & & & & 9 & Standaard & 150 & 11 & dicht & I \\
\hline $21^{P}$ & $47^{x}$ & & $99^{F}$ & 10 & Ruitzaai onbemest & - & 11 & dicht & J \\
\hline $\mathrm{N}$ & $R$ & z & $\mathrm{P}$ & 11 & Ruitzaai & 100 & 8 & open & $\mathrm{K}$ \\
\hline & & & & 12 & Ruitzaai & 100 & 8 & dicht & $\mathrm{L}$ \\
\hline${ }_{19}^{R}$ & ${ }_{45}^{G}$ & $V_{71} v$ & ${ }_{97} \mathrm{~V}$ & 13 & Ruitzaai & 100 & 11 & open & $M$ \\
\hline$x$ & & $x$ & $G$ & 14 & Ruitzaai & 100 & 11 & dicht & $\mathrm{N}$ \\
\hline $18 \wedge$ & $44^{\mathrm{A}}$ & & 96 & 15 & Ruitzaai & 150 & 8 & open & $\mathrm{O}$ \\
\hline$z$ & $\mathrm{~J}$ & 1 & $\mathrm{D}$ & 16 & Ruitzaai & 150 & 8 & dicht & $\mathrm{P}$ \\
\hline & & & & 17 & Ruitzaai & 150 & 11 & open & $\mathrm{Q}$ \\
\hline $16^{M}$ & $42^{P}$ & $68^{M}$ & $94^{C}$ & 18 & Ruitzaai & 150 & 11 & dicht & $\mathrm{R}$ \\
\hline c & $Y$ & L & A & 19 & Drijfmestrijenbemesting & 100 & 8 & open & $\mathrm{S}$ \\
\hline & & & & 20 & Drijfmestrijenbemesting & 100 & 8 & dicht & $\mathrm{T}$ \\
\hline $14^{w}$ & $40^{L}$ & $66 s$ & ${ }_{92} \mathrm{~S}$ & 21 & Drijfmestrijenbemesting & 100 & 11 & open & $\mathrm{U}$ \\
\hline y & & G & $N$ & 22 & Drijfmestrijenbemesting & 100 & 11 & dicht & V \\
\hline & & & $91 \mathrm{~N}$ & 23 & Drijfmestrijenbemesting & 150 & 8 & open & W \\
\hline$T$ & c & J & $R$ & 24 & Drijfmestrijenbemesting & 150 & 8 & dicht & $\mathrm{X}$ \\
\hline & & & & 25 & Drijfmestrijenbemesting & 150 & 11 & open & $\mathrm{Y}$ \\
\hline $11^{\prime}$ & $3_{37^{W}}$ & $6^{\mathrm{T}}$ & $89^{\mathrm{U}}$ & 26 & Drijfmestrijenbemesting & 150 & 11 & dicht & Z \\
\hline${ }_{10}^{G}$ & ${ }_{36} \mathrm{~s}$ & & & & & & & & \\
\hline $9^{\text {B }}$ & $35 \mathrm{z}$ & $61{ }^{6}$ & $87^{H}$ & & & & & & \\
\hline $8 \quad 4$ & $34^{k}$ & $60^{A}$ & $86^{M}$ & & & & & & \\
\hline $7^{v}$ & $33^{\mathrm{M}}$ & $59^{H}$ & 85 L & & & & & & \\
\hline $6^{D}$ & $32^{N}$ & $588^{N}$ & $84^{w}$ & & & & & & \\
\hline $5_{5}^{H}$ & ${ }_{31}$ U & $57^{C}$ & $83^{Y}$ & & & & & & \\
\hline $4^{S}$ & $30^{\mathrm{F}}$ & $56{ }^{K}$ & & & & & & & \\
\hline $3^{Q}$ & $29^{\top}$ & $55^{\mathrm{D}}$ & $81^{J}$ & & & & & & \\
\hline $2^{J}$ & $28 \mathrm{~V}$ & $54^{P}$ & $80^{\prime}$ & & & & & & \\
\hline $1^{\mathrm{K}}$ & $27 E$ & $5^{\circ}{ }^{\circ}$ & $79^{z}$ & & & & & & \\
\hline bruto & bruto & bruto & bruto & & & & & & \\
\hline $12 \mathrm{~m}$ & $12 \mathrm{~m}$ & $12 \mathrm{~m}$ & $12 \mathrm{~m}$ & & & & & & \\
\hline
\end{tabular}

Figuur 1 Verdeling van de behandelingen over de plots in een volledig gewarde blokkenproef met vier herhalingen. 


\section{2}

Locatie

De proef werd uitgevoerd op een perceel van proefbedrijf Vredepeel te Vredepeel $\left(51^{\circ} 32^{\prime} 40^{\prime \prime} \mathrm{N}\right.$, $5^{\circ} 51^{\prime} 40^{\prime \prime} \mathrm{O}$ ). De grondsoort is zandgrond dat wordt getypeerd als een veldpodzol (jonge ontginningsgrond) met leemarm en zwak lemig zand ( $\mathrm{Hn} 21$ ). De bouwvoordiepte is gemiddeld 25-30 $\mathrm{cm}$ en de bewortelingsdiepte is geschat op 30-40 cm. Het perceel heeft een grondwatertrap van GT VII (GHG 80-140 cm en GLG >120 cm). Het perceel is een permanent bouwlandperceel en de voorvruchten in de drie jaren voorafgaand aan proef waren: triticale (2013), snijmais (2014) en schorseneren (2015).

In de winter of in het voorjaar is voorafgaand aan de bemesting een grondmonster genomen. Tabel 1 toont de resultaten van de bodemanalyses in de laag 0-25 cm voor de proefjaren 2016 t/m 2019.

Tabel 1 Resultaten van bodemanalyses in de laag 0-25 cm voor de proefjaren 2016 t/m 2019.

\begin{tabular}{|c|c|c|c|c|}
\hline & 2016 & 2017 & 2018 & 2019 \\
\hline Monsterdatum & 7 december 2015 & 17 maart & 14 maart & 14 maart \\
\hline Organische stof (\%) & 4,3 & 4,7 & 4,7 & 4,8 \\
\hline $\mathrm{pH}$ & 5,4 & 5,1 & 5,1 & 5,4 \\
\hline Klei-humus CEC (mmol+/kg) & 57 & 60 & 69 & 79 \\
\hline CEC-bezetting (\%) & 97 & 91 & 90 & 75 \\
\hline N-bodemvoorraad (mg N/kg) & 1420 & 1380 & 1510 & 1580 \\
\hline NLV (kg N/ha) & 49 & 40 & 60 & 60 \\
\hline $\mathrm{P}-\mathrm{AL}\left(\mathrm{mg} \mathrm{P} \mathrm{P}_{2} \mathrm{O}_{5} / 100 \mathrm{~g}\right)$ & 47 & 49 & 52 & 52 \\
\hline P-PAE (mg P/kg) & 3,4 & 3,7 & 2,8 & 2,6 \\
\hline $\mathrm{Pw}\left(\mathrm{mg} \mathrm{P}_{2} \mathrm{O}_{5} / \mathrm{l}\right)$ & 48 & 51 & 48 & 46 \\
\hline $\mathrm{K}-\mathrm{PAE}(\mathrm{mg} \mathrm{K} / \mathrm{kg})$ & 71 & 51 & 49 & 60 \\
\hline K-bodemvoorraad $(\mathrm{mmol}+/ \mathrm{kg})$ & 2,0 & 1,7 & 1,9 & 2,2 \\
\hline K-getal & & 12 & 11 & 14 \\
\hline Mg-PAE (mg Mg/kg) & 151 & 155 & 157 & 166 \\
\hline SLV (kg S/ha) & 9 & 9 & 9 & 11 \\
\hline S-PAE (mg S/kg) & & $<4$ & 1,8 & 2,7 \\
\hline B-PAE ( $\mu \mathrm{g} \mathrm{B/kg)}$ & & & 552 & \\
\hline
\end{tabular}

$\mathrm{CEC}=$ cation exchange capacity; $\mathrm{NLV}=\mathrm{N}$ leverend vermogen; $\mathrm{P}-\mathrm{AL}=\mathrm{P}$ extractie met ammonium lactaat; $\mathrm{PAE}=\mathrm{plant}$ available element, extractie met $0.1 \mathrm{M} \mathrm{CaCl}_{2} ; \mathrm{PW}=\mathrm{P}$ extractie met water; $\mathrm{SLV}=$ zwavel leverend vermogen

2.3

\section{Proefuitvoering}

Tabel 2 toont de verschillende teeltactiviteiten met de gerealiseerde data in de vier proefjaren 2016 t/m 2019. 


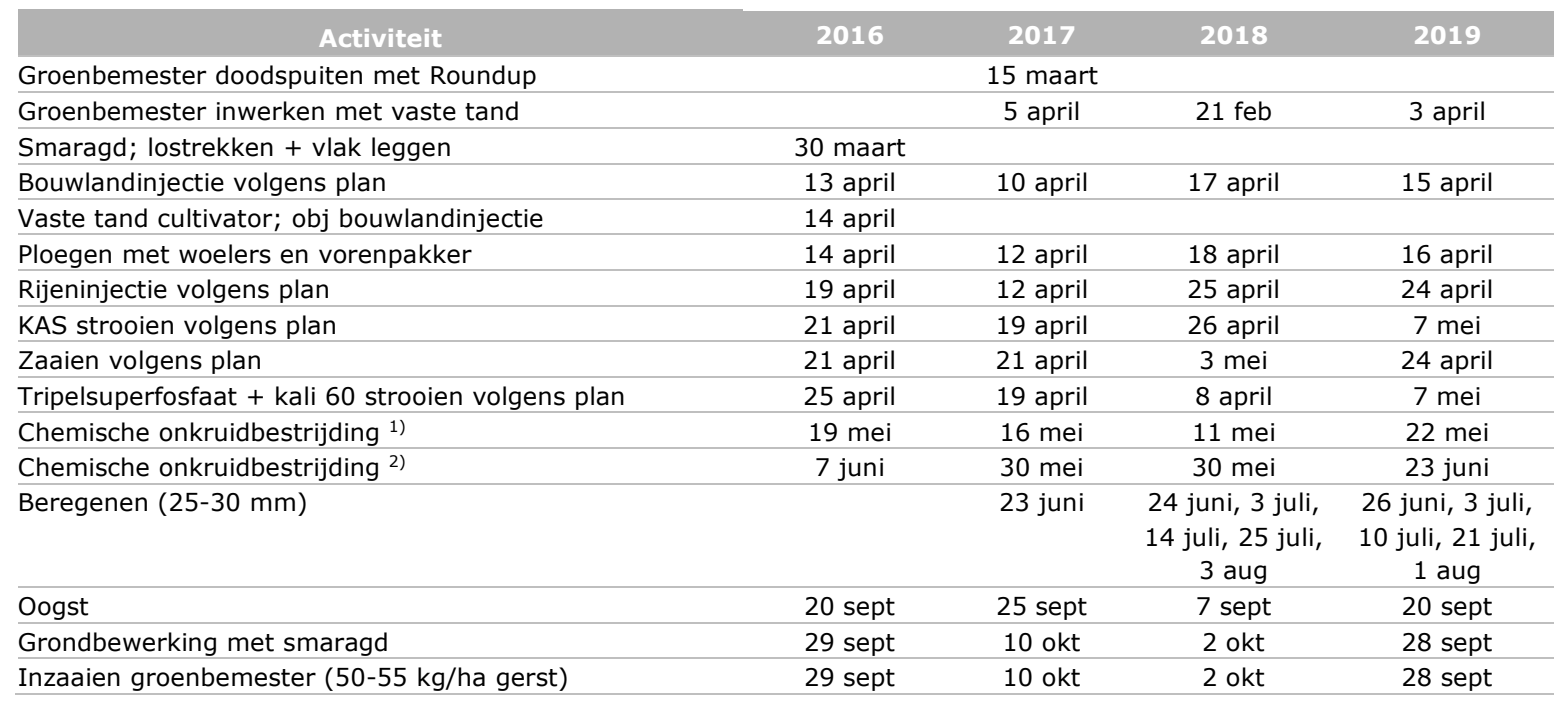

1) 2016: 0,3 I Calaris + 1,0 I Gardo Gold per ha; 2017: 0.25 I Sulcogan + 1 I Akris per ha; 2018: 0,25 I/ha Sulcogan + 1,0 I/ha Gardo Gold; 2019: 0,3 I/ha Calaris + 0,25 I/ha Sulcogan + 0,2 I/ha Samson OD + 0,3 I/ha Kart

2) 2016: 0,3 I Sulcogan + 1,5 I Arkis + 0,2 I Samson + 0,3 I Kart per ha; 2017: 0.3 I Calaris + 0.5 I Kart + 0.4 I Samson Od + 1.3 I Gardo Gold per ha; 2018: 0,3 I/ha Calaris + 0,5 I/ha Kart + 0,3 I/ha Samson Od + 1,5 I/ha Akris; $2019: 0,8 \mathrm{l} / \mathrm{ha}$ Laudis $+0,3 \mathrm{I} /$ ha Calaris $+0,3 \mathrm{I} / \mathrm{ha}$ Samson OD $+0,4 \mathrm{l} / \mathrm{ha}$ Kart

De hoofdgrondbewerking bij alle drie teeltmethoden bestond uit ploegen. De ploegdiepte was ongeveer $25 \mathrm{~cm}$. Aan de ploeg waren woelers (ondergronders) gemonteerd die tot $30 \mathrm{~cm}$ diepte werkten. Bij de teeltmethode standaard en ruitzaai werd de bouwlandinjectie uitgevoerd voor het ploegen en bij de teeltmethode drijfmestrijenbemesting werd de rijeninjectie uitgevoerd na het ploegen. Figuur 2 is een afbeelding van de beide methoden voor aanwenden van drijfmest. Bouwlandinjectie werd toegepast bij de teeltmethoden standaard en ruitzaai en rijeninjectie bij drijfmestrijenbemesting. De injectietanden bij bouwlandinjectie zaten op een onderlinge afstand van $25 \mathrm{~cm}$ en de werkdiepte was $15 \mathrm{~cm}$. De injectietanden bij drijfmestrijenbemesting zaten op $9 \mathrm{~cm}$ afstand aan weerszijden van de toekomstige maisrij. In de detailfoto van de drijfmestrijenbemesting in figuur 2 is te zien dat er een rij woelers $(30 \mathrm{~cm})$ vooraf gaan aan de injectietanden $(10-15 \mathrm{~cm})$ en worden gevolgd door een tweede rij woelers $(10 \mathrm{~cm})$. De bemesters waren bevestigd aan een Vervaet Hydrotrike mestvoertuig (driewielige zelfrijdende bemester). De bandenspanning tijdens het uitrijden was 2,2 bar. Figuur 3 is een afbeelding van de verschillende methoden voor inzaaien met links standaardzaai $(75 \mathrm{~cm})$ en rechts ruitzaai $(35,5 \mathrm{~cm})$. Bij ruitzaai was de trekker uitgerust met brede banden met een lage bandenspanning van 0,7 bar om bodemverdichting zoveel mogelijk te voorkomen omdat i.v.m. de rijafstand van $37,5 \mathrm{~cm}$ ook maisrijen in de sporen van de trekker worden gezaaid.

De kunstmest werd volvelds toegediend met een pneumatische strooier, vlak voor of na het mais zaaien. 

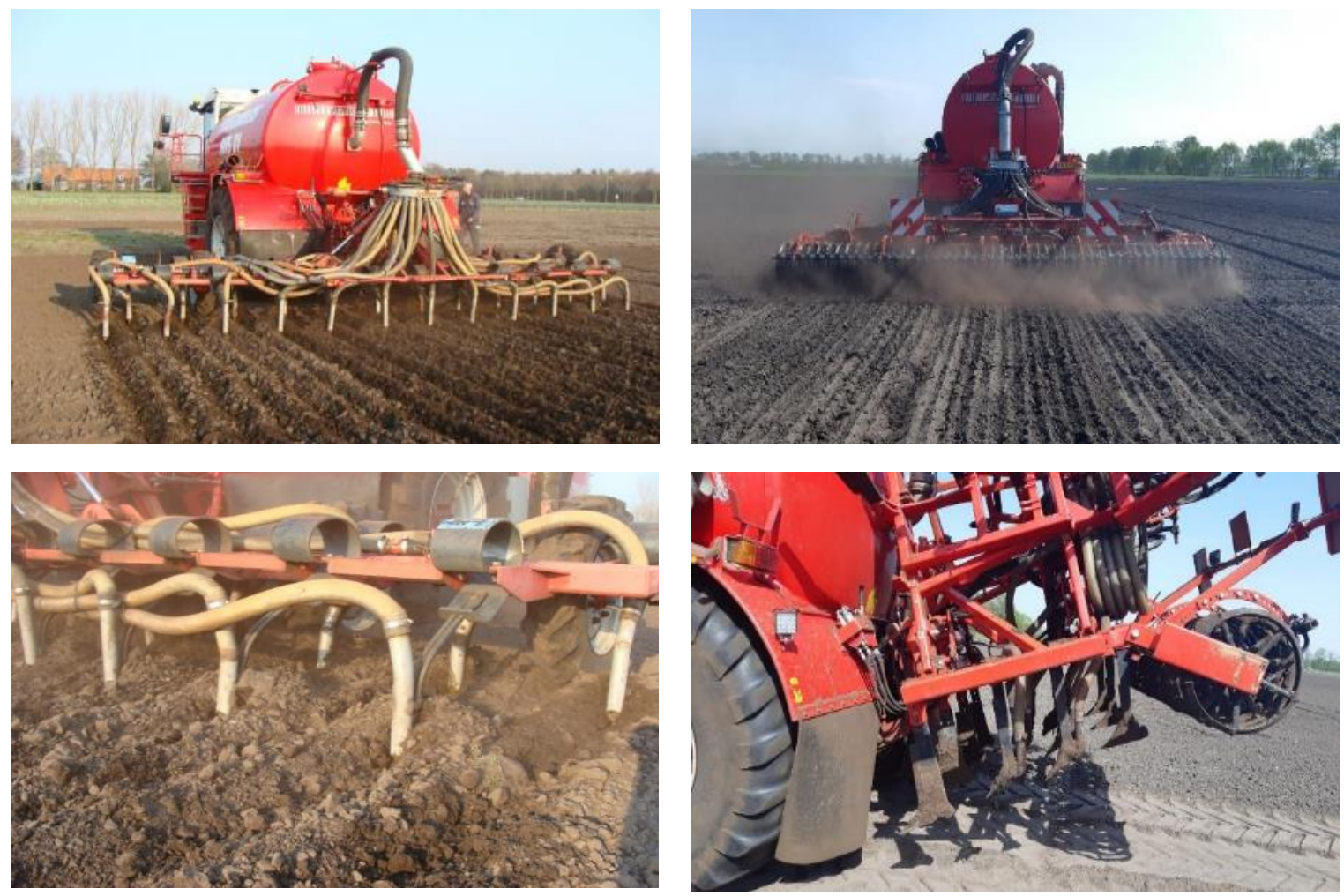

Figuur 2 De twee methoden van drijfmest aanwenden met links bouwlandinjectie (bij de teeltmethoden Standaard- en Ruitzaai) en rechts rijeninjectie (bij de teeltmethode Drijfmestrijenbemesting)
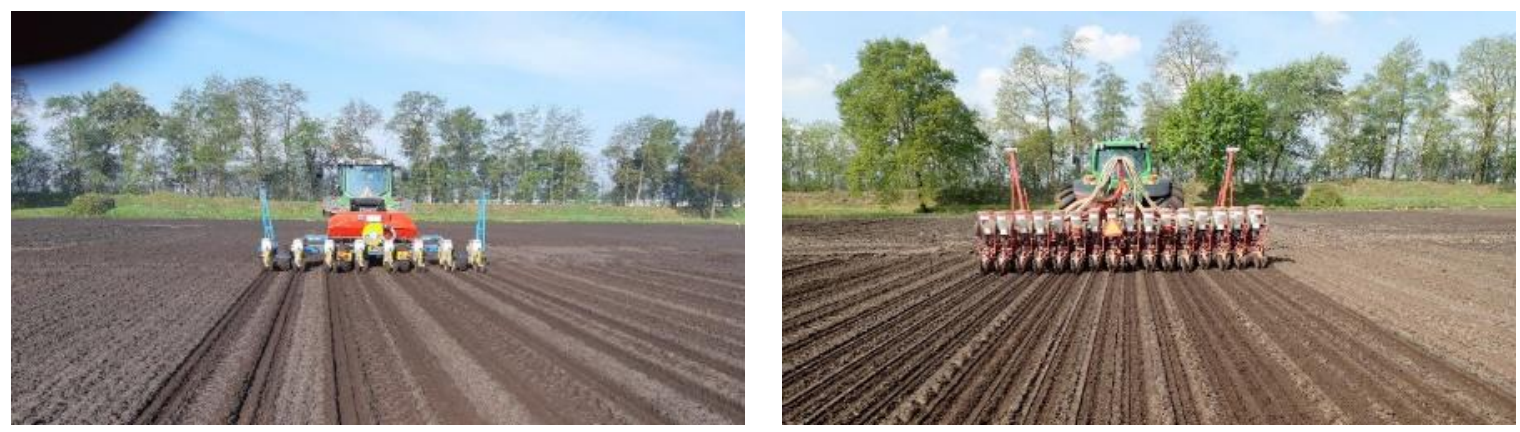

Figuur 3 De verschillende methoden voor inzaaien met links standaardzaai $(75 \mathrm{~cm})$ en rechts ruitzaai $(35.5 \mathrm{~cm})$.

Voor zowel het rastype met relatief brede bladstand (dicht gewas) en het rastype met relatief steile bladstand (open gewas) is bij het zaaien getracht een plantaantal van 80.000 en 110.000 planten per hectare te behalen. Na inzaai is begin juni de opkomst gekwantificeerd om indien nodig de plantaantallen uit de dunnen tot het gewenste aantal.

\section{$2.4 \quad$ Bemesting}

Op alle behandelingen werd $30 \mathrm{~m}^{3} \mathrm{ha}^{-1}$ runderdrijfmest uitgereden. De dosering werd geregeld m.b.v. een doorstroommeter en een boordcomputer. Tabel 3 toont de resultaten van de samenstelling van de drijfmest voor de proefjaren $2016 \mathrm{t} / \mathrm{m}$ 2019. De samenstelling was redelijk constant over de jaren heen. In vergelijking met de forfaitaire normen van $4.0 \mathrm{~g} \mathrm{~kg}^{-1} \mathrm{~N}, 1.5 \mathrm{~g} \mathrm{~kg}^{-1} \mathrm{P}_{2} \mathrm{O}_{5}$ was het $\mathrm{N}$-gehalte vergelijkbaar, maar het $\mathrm{P}_{2} \mathrm{O}_{5}$ en $\mathrm{K}_{2} \mathrm{O}$ gehalte wat lager. Het is een wat dunne mest met laag ds gehalte.

De N/P ratio is hoger dan standaard. 
Tabel 3 Samenstelling van de drijfmest $\left(\mathrm{g} \mathrm{kg}^{-1}\right)$ in de jaren 2016, 2017, 2018 en 2019.

\begin{tabular}{|c|c|c|c|c|}
\hline & $2016^{1)}$ & $2017^{1)}$ & $2018^{1)}$ & $2019^{1)}$ \\
\hline Drogestof & 74 & 70 & 71 & 68 \\
\hline Ruw as & 15 & 15 & 15 & 15 \\
\hline Org.stof & 59 & 54 & 56 & 53 \\
\hline N-totaal & 4,07 & 3,98 & 3,87 & 4,05 \\
\hline $\mathrm{N}-\mathrm{NH}_{4}$ & 2,3 & 2,2 & 2,1 & 2,2 \\
\hline N-Org & 1,8 & 1,8 & 1,8 & 1,9 \\
\hline $\mathrm{P}_{2} \mathrm{O}_{5}$ & 1,27 & 1,24 & 1,19 & 1,17 \\
\hline $\mathrm{K}_{2} \mathrm{O}$ & 5,0 & 5,1 & 4,3 & 4,4 \\
\hline $\mathrm{MgO}$ & 1,1 & 1,2 & 1,3 & 1,4 \\
\hline $\mathrm{Na}_{2} \mathrm{O}$ & 1,2 & 1,4 & 1,3 & 0,8 \\
\hline
\end{tabular}

1) Gemiddelde van twee monsters

De stikstofbemesting werd afhankelijk van het $\mathrm{N}$-bemestingsniveau volvelds aangevuld met 25 of 80 $\mathrm{kg} \mathrm{N}$ per ha in de vorm van KAS. De fosfaatbemesting werd aangevuld met $25 \mathrm{~kg} \mathrm{P}_{2} \mathrm{O}_{5}$ per ha in de vorm van tripelsuperfosfaat en de kalibemesting werd aangevuld met $150 \mathrm{~kg} \mathrm{~K}{ }_{2} \mathrm{O}$ per ha in de vorm van kali 60 . In tabel 4 zijn de gerealiseerde nutriëntengiften uit drijfmest en kunstmest weergegeven, gemiddeld over de vier proefjaren.

Tabel 4 Nutrientengiften uit drijfmest en kunstmest $\left(\mathrm{kg} \mathrm{ha}^{-1}\right)$, gemiddeld over de jaren $2016 \mathrm{t} / \mathrm{m}$ 2019.

\begin{tabular}{|c|c|c|c|}
\hline & \multicolumn{3}{|c|}{ N-niveau } \\
\hline & 0 & 100 & 150 \\
\hline \multicolumn{4}{|l|}{ Drijfmest } \\
\hline N-totaal & 0 & 121 & 121 \\
\hline $\mathrm{N}-\min$ & 0 & 66 & 66 \\
\hline $\mathrm{N}$-org & 0 & 55 & 55 \\
\hline $\mathrm{P}_{2} \mathrm{O}_{5}$ & 0 & 37 & 37 \\
\hline $\mathrm{K}_{2} \mathrm{O}$ & 0 & 141 & 141 \\
\hline \multicolumn{4}{|l|}{ Kunstmest } \\
\hline N-totaal & 0 & 15 & 70 \\
\hline $\mathrm{N}-\min$ & 0 & 15 & 70 \\
\hline $\mathrm{P}_{2} \mathrm{O}_{5}$ & 65 & 25 & 25 \\
\hline $\mathrm{K}_{2} \mathrm{O}$ & 300 & 150 & 150 \\
\hline \multicolumn{4}{|l|}{ Totaal } \\
\hline N-totaal & 0 & 136 & 191 \\
\hline $\mathrm{N}-\min$ & 0 & 81 & 136 \\
\hline $\mathrm{N}$-org & 0 & 55 & 55 \\
\hline N-werkzaam¹) & 0 & 91 & 146 \\
\hline $\mathrm{P}_{2} \mathrm{O}_{5}$ & 65 & 62 & 62 \\
\hline $\mathrm{K}_{2} \mathrm{O}$ & 300 & 291 & 291 \\
\hline
\end{tabular}

1) Berekend o.b.v. N-werkingscoëfficiënten bij bouwlandinjectie in maart/april (www.bemestingsadvies.nl)

\section{$2.5 \quad$ Groeiomstandigheden}

Op proefbedrijf Vredepeel is een weerstation aanwezig dat o.a. dagelijks de temperatuur en neerslag registreert. Figuur $4 \mathrm{a}$ en $4 \mathrm{~b}$ tonen respectievelijk de neerslag en de temperatuur per decade voor de jaren 2016, 2017, 2018, 2019 en daarnaast een dertigjarig gemiddelde ter referentie.

\section{Neerslag}

In het groeiseizoen van 2016 viel er totaal $54 \mathrm{~mm}$ meer neerslag dan het dertigjarig gemiddelde. Dit werd met name veroorzaakt door het eerste deel van het groeiseizoen, met name de pieken in neerslag in mei en juni vallen op. In zowel 2017, 2018 en 2019 viel er minder neerslag dan het dertigjarig gemiddelde. In 2018 viel de minste neerslag met in totaal $196 \mathrm{~mm}$ minder dan het dertigjarig gemiddelde en was het met name in het tweede deel van het seizoen droger. In 2019 viel in totaal $127 \mathrm{~mm}$ minder dan het dertigjarig gemiddelde. In beide droge jaren is daarom vijf keer beregend met 25-30 $\mathrm{mm}$ per keer. 


\section{Temperatuur}

Met name in de groeiseizoenen van 2016 en 2018 lag het grootste deel van de gemiddelde maandtemperatuur hoger dan het dertigjarig gemiddelde. In 2016 waren met name de maanden mei en september warmer en in 2018 vooral de zomermaanden juni, juli en augustus.

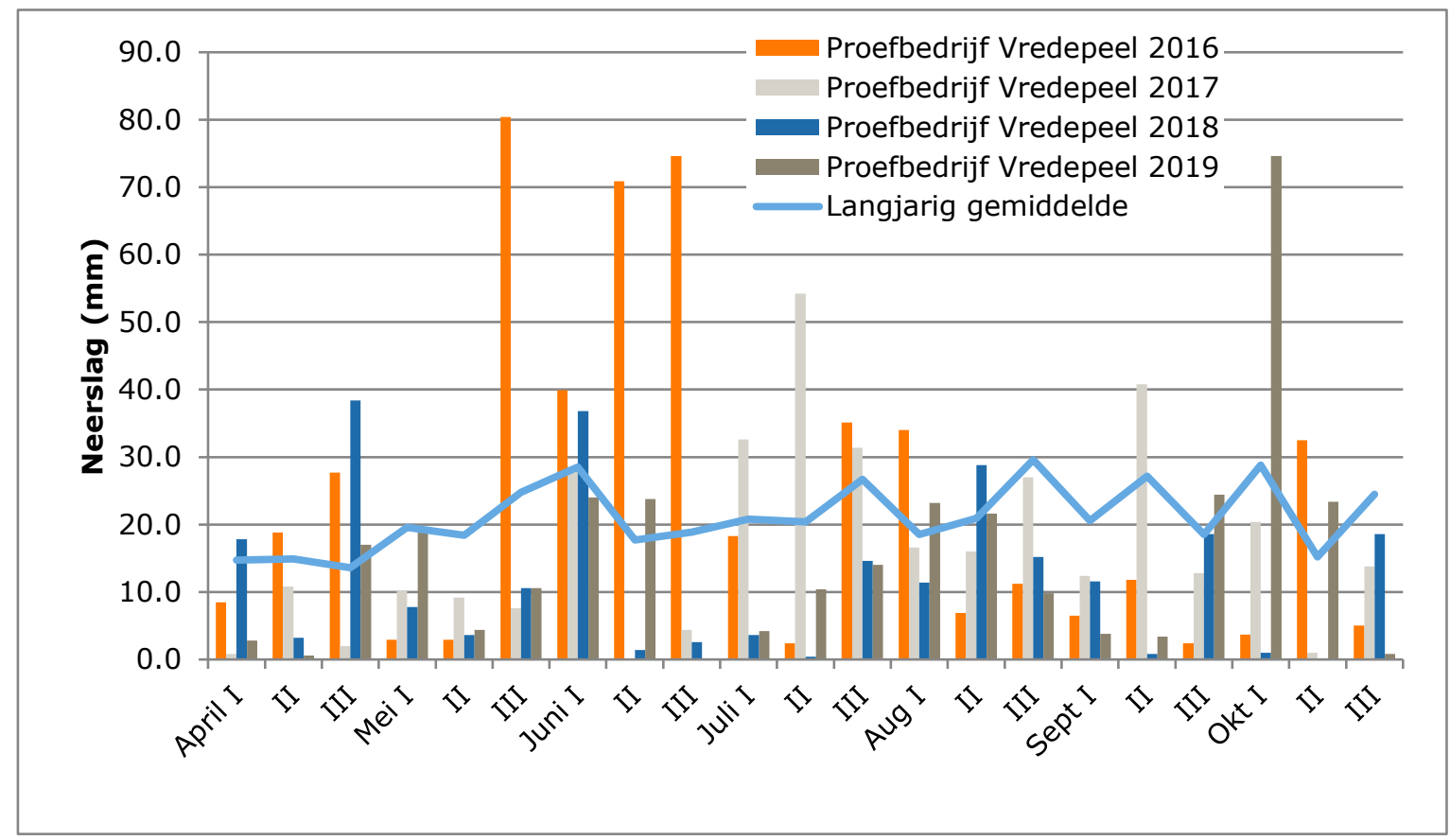

Figuur 4a Neerslag per decade op de proeflocatie voor de jaren 2016, 2017, 2018, 2019 en een dertigjarig gemiddelde (bron KNMI).

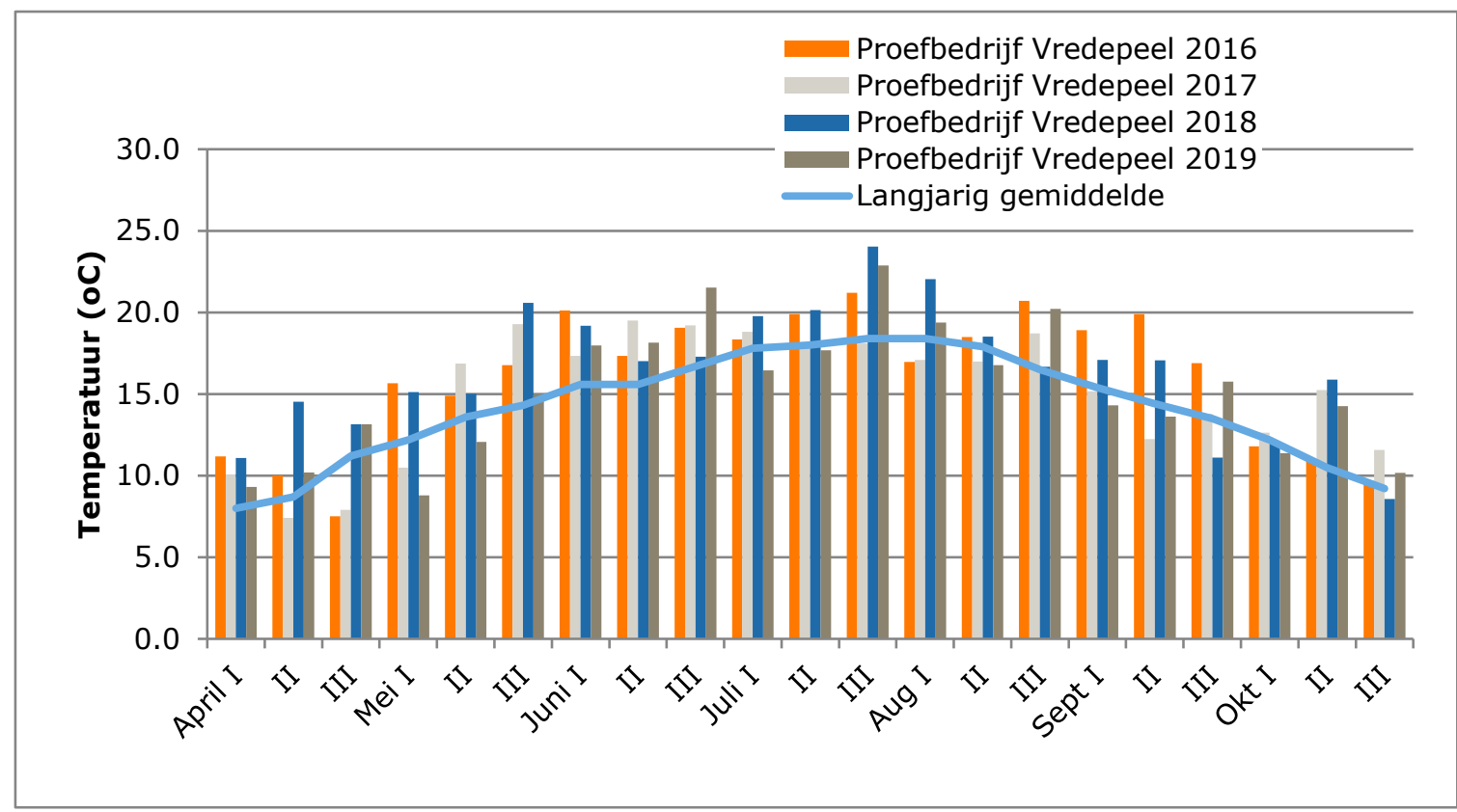

Figuur $4 \boldsymbol{b}$ Gemiddelde temperatuur per decade op de proeflocatie voor de jaren 2016, 2017, 2018, 2019 en een dertigjarig gemiddelde (bron KNMI). 


\subsubsection{Maisopbrengst}

De maïs werd geoogst met een proefveldhakselaar. Dit is een trekker waar voorop een tweerijige radhakselaar gemonteerd is en achterop een weeginrichting zit. Van alle behandelingen werd per veldje de maïsopbrengst van de netto-oppervlakte (4 rijen met een lengte van 10,2 m) gewogen. Uit het gehakselde materiaal werden per veldje twee monsters van circa 750 gram genomen. Eén monster werd gedroogd bij $105^{\circ} \mathrm{C}$ voor bepaling van het gehalte aan drogestof (DS) en het tweede monster werd vers opgestuurd naar Eurofins-Agro. Op basis van het verse gewicht en het gemiddelde DS-gehalte van de beide monsters werd de DS-opbrengst berekend.

\subsubsection{Gewasanalyse}

Het tweede monster dat werd opgestuurd naar Eurofins-Agro werd geanalyseerd op verteerbaarheid organische stof (VCOS) en op de volgende gehaltes: DS, zetmeel, N-totaal, P-totaal, ruwe celstof ( $r c$ ), ruw eiwit (re) en ruw as (ras). DS-gehalte, restvocht en ruwe as werden nat-chemisch bepaald en de andere gehalten op basis van NIRS. Het N-gehalte is bepaald op basis van het re gehalte met omrekeningsfactor 6.25. Op basis van de VCOS en chemische samenstelling werd de voederwaarde (VEM, DVE en OEB) berekend volgens de voorschriften van het Centraal Veevoederbureau (CVB, 2007). De $\mathrm{N}$-recovery is berekend door de totale $\mathrm{N}$-opbrengst te verminderen met de gemiddelde $\mathrm{N}$ opbrengst van veldjes zonder $\mathrm{N}$-bemesting en vervolgens te delen door de totale $\mathrm{N}$-bemesting.

\subsubsection{Tussenoogst}

In de jaren 2016 t/m 2018 is er eind mei-begin juni een tussenoogst uitgevoerd. Hiervoor zijn de volgende 8 objecten uitgekozen: $D, E, M, N, U$ en $V$. Deze objecten vormen een selectie van alle drie de teeltmethoden bij een laag $\mathrm{N}$ niveau, hoog plantaantal en beide rastypen en daarnaast de beide onbemeste veldjes. Bij vier herhalingen geeft dit dus een totaal van 8 veldjes per teeltmethode. Per veldje zijn 4 rijen voor standaardzaai en 8 rijen voor ruitzaai geoogst met een lengte van 1 meter (Figuur 5). Per veldje is eerst het aantal geoogste planten geteld en het vers gewicht bepaald. Daarna zijn de planten gehakseld en is een monster genomen voor de bepaling van het DS-gehalte.

$6 \mathrm{~m}$

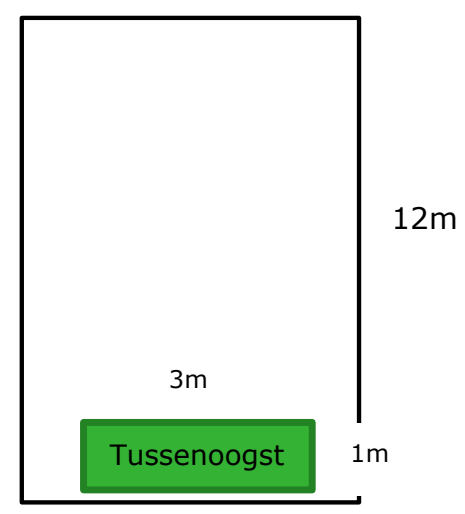

Figuur 5 Schematische weergave tussenoogst per veldje. 
Om vast te stellen of en in welke mate de factoren "teeltmethode" en "rastype" effect hebben op de beworteling van de maïs wat betreft patroon en massa zijn er wortelbepalingen gedaan. In $2016 \mathrm{t} / \mathrm{m}$ 2018 is jaarlijks tweemaal een bemonstering van de wortelverdeling en -massa gedaan in 6 objecten in de proef: $D, E, M, N, U$, en $V$. Deze objecten vormen een selectie van de drie de teeltmethoden (Standaard, Ruitzaai en Drijfmestrijenbemesting) bij een laag N niveau, hoog plantaantal en beide rastypen. Bij vier herhalingen geeft dit een totaal van 8 veldjes per teeltmethode. Per veldje werden 4 monsters genomen met een grondboor (Figuur 6), elk bestaand uit 5 submonsters van elk $\varnothing 8 \mathrm{~cm}$ en $15 \mathrm{~cm}$ hoog (ca. $0.75 \mathrm{~L}$ ).

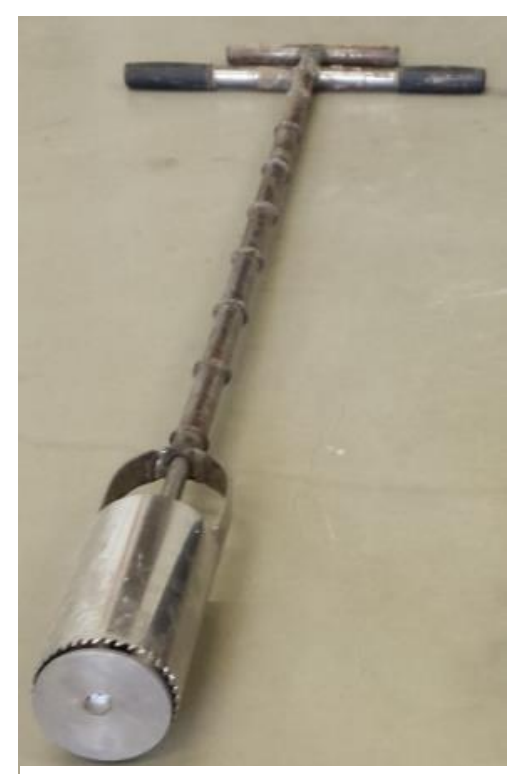

Figur 6 Grondboor voor wortelbepalingen.

Er werd gemonsterd op 5 en $20 \mathrm{~cm}$ vanaf de plantvoet (hartafstand plantvoet en midden boor). Vanaf 2017 werd bij de veldjes met standaardzaai een $5^{e}$ monster genomen, op 37,5 cm vanaf de plantvoet (midden tussen de rijen) (Figuur 7). De eerste bemonstering vond plaats als het gewas op een hoogte van ca 1,5 m was (9-bladstadium) en de tweede direct na de oogst. In 2016 werd bemonsterd op 29 juni en 24 september, in 2017 op 28 juni en 26 september en in 2018 op 5 juli en 27 september. De monsters werden schoongespoeld, en ontdaan van wortelmassa van andere soorten dan mais. Daarna werd de DS massa bepaald.

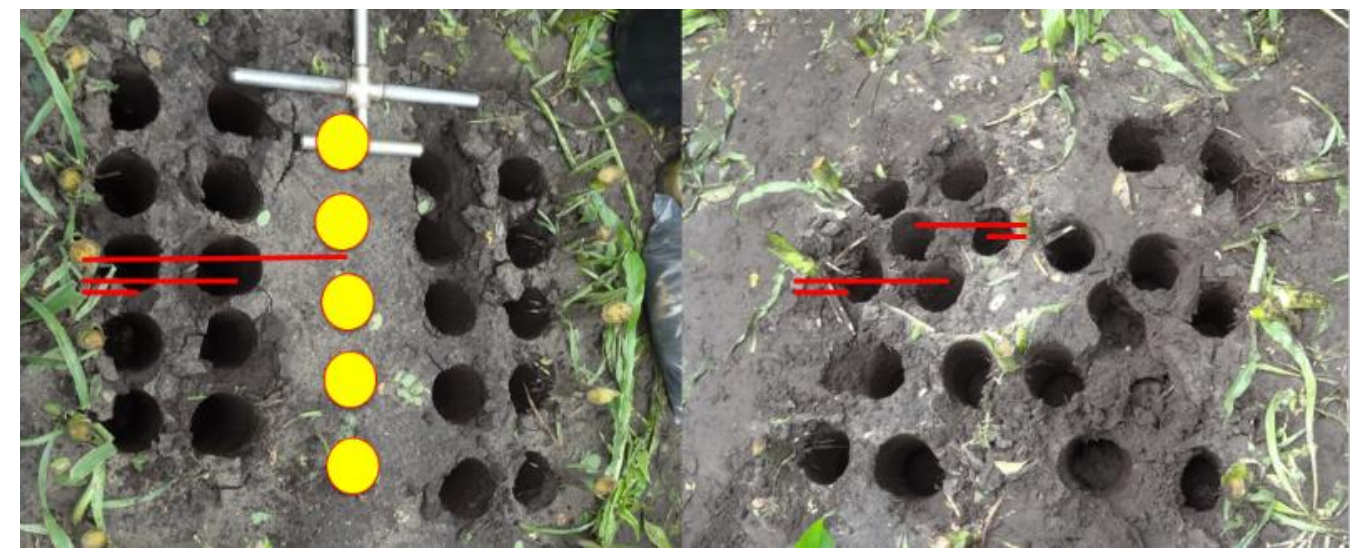

Figur 7 Grafische weergave van de grondmonsters per veldje voor standaardzaai (links) en ruitzaai (rechts). 


\section{6 .5}

Om inzicht te krijgen in mogelijke verschillen tussen de teeltmethoden in de verdichting van de bodem door bemesten en zaaien is eind mei/begin juni de dichtheid in de bovenlaag van de bodem gemeten met een penetrometer in de jaren 2017-2019. De volgende objecten zijn uitgekozen voor de bodemmetingen: D, G, M, P, U en X. Deze objecten vormen een selectie van alle drie de teeltmethoden. Per teeltmethode zijn twee objecten gekozen. Het ene object was een combinatie van laag N-niveau*hoog plantaantal*open ras en het andere een combinatie van hoog N-niveau*laag plantaantal*dicht ras. Bij vier herhalingen geeft dit een totaal van 8 veldjes per teeltmethode. Per veldje zijn haaks op de zaairichting 20 metingen uitgevoerd met een prikafstand van $25 \mathrm{~cm}$ (Figuur 8). Door de penetrometer werd op elke $\mathrm{cm}$ diepte de indringingsweerstand vastgelegd. Uit de resultaten werd per meetpunt de gemiddelde indringingsweerstanden in de laag 10-35 cm berekend uit 25 waarden die waren vastgelegd tussen 10 en $35 \mathrm{~cm}$ diepte.
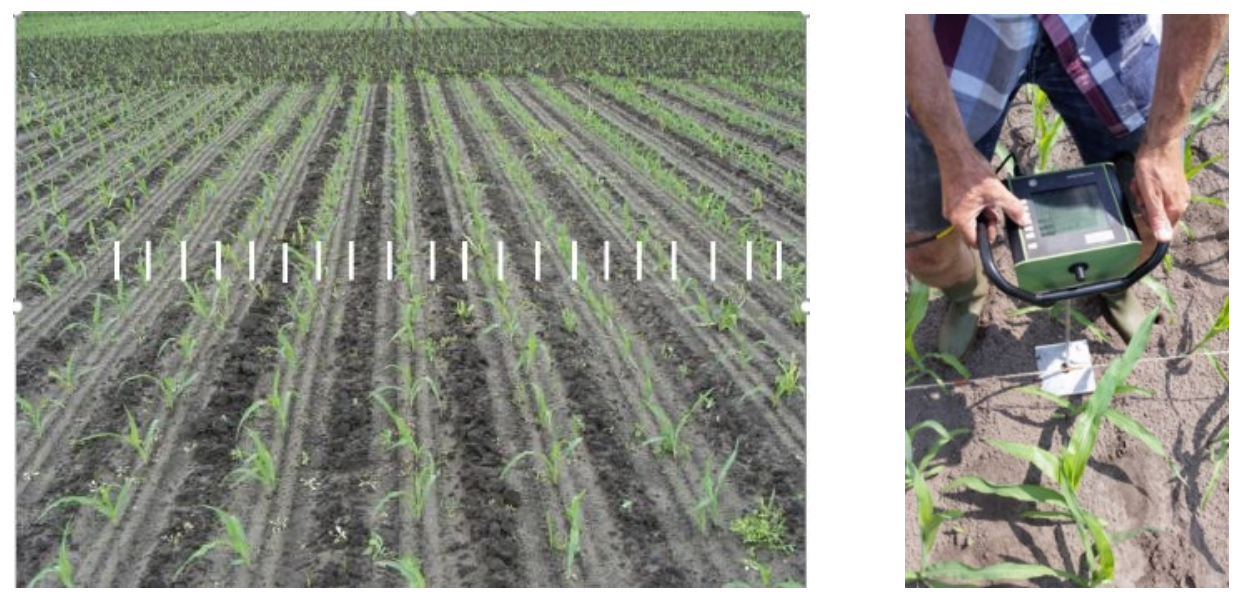

Figuur 8 Aanduiding van 20 meetpunten per veldje (links) voor bepaling van dichtheid in de bovenlaag van de bodem $(10-35 \mathrm{~cm})$ gemeten met een penetrometer (rechts) met een prikafstand van $25 \mathrm{~cm}$.

\section{$\mathbf{2 . 7}$}

\section{Statistische analyse}

Door de proefzet (volledig gewarde blokkenproef) was het mogelijk om een integrale analyse uit te voeren over jaren heen op basis van een variantie-analyse (ANOVA procedure) met alle proefobjecten. De analyse van de herhaalde waarnemingen is uitgevoerd met het split plot principe. In feite wordt voor ieder veldje de gemiddelde opbrengst van 4 jaren berekend, en vervolgens worden de behandelingseffecten (gemiddeld over jaren heen) getoetst. Hiervoor is het statistische programma Genstat gebruikt. Voor de analyse van de wortelbepalingen is de ATTEST-procedure gebruikt.

Het statistische model zag er als volgt uit:

$$
\begin{aligned}
& \mathrm{y}_{\mathrm{ijkl}}=\mu+\mathrm{T}_{\mathrm{i}}+\mathrm{N}_{\mathrm{j}}+\mathrm{R}_{\mathrm{k}}+\mathrm{A}_{\mathrm{l}}+\mathrm{TN}_{\mathrm{ij}}+\mathrm{TA}_{\mathrm{ik}}+\mathrm{TR}_{\mathrm{il}}+\mathrm{NR}_{\mathrm{ik}}+\mathrm{NA}_{\mathrm{jl}}+\mathrm{RA}_{\mathrm{kl}}+\mathrm{TNR}_{\mathrm{ijk}}+\mathrm{TNA}_{\mathrm{ijl}} \\
& +\mathrm{TRA}_{\mathrm{ikl}}+\mathrm{NRA}_{\mathrm{jkl}}+\mathrm{TYr}_{\mathrm{im}}+\mathrm{NYr}_{\mathrm{jm}}+\mathrm{RYr}_{\mathrm{km}}+\mathrm{AYr}_{\mathrm{lm}}+\mathrm{B}_{\mathrm{n}}+\mathrm{V} \cdot \mathrm{B}_{\mathrm{no}}+\mathrm{Byr}_{\mathrm{mn}} \\
& + \text { V.BYr } r_{m n o}+\epsilon_{\mathrm{ijkl}}
\end{aligned}
$$

Met voor $\mathrm{y}_{\mathrm{ijkl}}$ de gewasopbrengsten, gewasparameters en $\mathrm{N}$ recovery. De fixed hoofdeffecten zijn als volgt: $T_{i}$ is de teeltmethode ( $i$; standaard, ruitzaai of drijfmestrijenbemesting), $N_{j}$ het $N$ niveau ( $j ; 100$

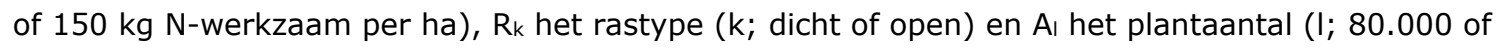
$110.000 \mathrm{pl} / \mathrm{ha}) . \mathrm{TA}_{i k}, \mathrm{TR}_{i \mathrm{il}}, \mathrm{NR}_{i \mathrm{k}}, \mathrm{NA}_{\mathrm{jl}}, \mathrm{RA}_{\mathrm{kl}}, \mathrm{TNR}_{\mathrm{ijk}}, \mathrm{TNA}_{\mathrm{ijl}}, \mathrm{TRA}_{i \mathrm{kl}}, \mathrm{NRA}_{\mathrm{jkl}}, \mathrm{TNRA}_{i j k l}$ zijn de interactie-effecten tussen de hiervoor gedefinieerde hoofdeffecten. Ook zijn de interactie-effecten tussen de hoofdeffecten en het jaar ( $\mathrm{Yr}_{\mathrm{m}}$ ) opgenomen ( $\mathrm{m} ; 2016,2017,2018$ of 2019). Verder zijn de random effecten als volgt: $B_{n}$ is het blokeffect ( $n$; blok I II III IV), V. $B_{n o}$ is het veld-binnen-blok effect ( 0 ; 1 , $2,3 \ldots$ of 26 ), Byrmn en V.BYrmno zijn de interactie-effecten tussen blok, veld-binnen-blok en jaar. 


\section{Resultaten}

\section{1}

Tussenoogst

Tabel 5 toont de gemiddelde resultaten over de jaren 2017 t/m 2019 van de tussenoogsten eind juni bij een $\mathrm{N}$-niveau van $100 \mathrm{~kg}$ per ha en een plantdichtheid van 11.000 per ha voor alle drie de teeltmethoden. Zowel de verse als de DS-opbrengst van de teeltmethode "drijfmestrijenbemesting" was lager vergeleken met de teeltmethoden "standaardzaai" en " ruitzaai". De verse opbrengst was bijna 5 ton/ha lager (ca. 13\%) en de DS-opbrengst bijna $350 \mathrm{~kg} / \mathrm{ha}$ (ca. 12\%). Er waren geen significante verschillen in DS-gehalten van de maisplanten tussen de drie teeltmethoden.

Tabel 5 Gemiddelde opbrengstresultaten van tussenoogsten eind juni voor de verschillende teeltmethoden (2016-2018).

\begin{tabular}{lccc} 
& Verse opbrengst (ton/ha) & $\begin{array}{c}\text { Teeltmethoden } \\
\text { Drogestof- } \\
\text { gehalte (\%) }\end{array}$ & $\begin{array}{c}\text { Drogestof- } \\
\text { opbrengst (kg/ha) }\end{array}$ \\
\hline Standaardzaai & $37.7^{\mathrm{b}}$ & 7.8 & $2880^{\mathrm{b}}$ \\
\hline Ruitzaai & $37.8^{\mathrm{b}}$ & 7.9 & $2920^{\mathrm{b}}$ \\
\hline Drijfmestrijenbemesting & $32.9^{\mathrm{a}}$ & 7.9 & $2560^{\mathrm{a}}$ \\
\hline P-waarde $(F)$ & 0.003 & 0.782 & 0.012
\end{tabular}

\section{2}

\section{Jaaropbrengsten en kwaliteit}

Tabel 6 toont de resultaten voor de gemiddelde jaaropbrengsten (2016-2019) inclusief gewasparameters en $\mathrm{N}$ recovery. Per factor zijn de resultaten weergegeven als gemiddelde over de andere factoren omdat er geen significante interactie-effecten zijn gevonden over de jaren heen tussen enerzijds de teeltmethoden en anderzijds $\mathrm{N}$-niveau, rastype en plantaantallen. De verse opbrengst was niet significant verschillend voor de verschillende teeltmethoden. De DS-opbrengst daarentegen was het hoogst voor de teeltmethode ruitzaai, gevolgd door standaardzaai en dan drijfmestrijenbemesting (respectievelijk $21.317 \mathrm{~kg} / \mathrm{ha}, 20.865 \mathrm{~kg} / \mathrm{ha}$ en $20.338 \mathrm{~kg} / \mathrm{ha} ; \mathrm{P}<0.001$ ). Deze verschillen worden veroorzaakt door een combinatie van numerieke verschillen in de verse opbrengst en significante verschillen in het DS-gehalte tussen de teeltmethoden. Het DS-gehalte was hoger voor de teeltmethode ruitzaai en standaardzaai vergeleken met drijfmestrijenbemesting (respectievelijk 40.3\%, 40.1\% en 39.6\%; P=0.049). De $\mathrm{N}$-opbrengst was hoger voor de teeltmethoden ruitzaai en standaardzaai vergeleken met drijfmestrijenbemesting (respectievelijk 225 $\mathrm{kg} / \mathrm{ha}, 222 \mathrm{~kg} / \mathrm{ha}$ en $216 \mathrm{~kg} / \mathrm{ha}(P=0.004)$. De fosfaatopbrengst van de teeltmethode ruitzaai was niet significant verschillend van standaardzaai, maar wel hoger vergeleken met drijfmestrijenbemesting (respectievelijk $86 \mathrm{~kg} / \mathrm{ha}, 84 \mathrm{~kg} / \mathrm{ha}$ en $82 \mathrm{~kg} / \mathrm{ha} ; \mathrm{P}=0.012$ ). De zetmeelopbrengst was hoger voor de teeltmethoden ruitzaai en standaardzaai vergeleken met drijfmestrijenbemesting (respectievelijk $7.838 \mathrm{~kg} / \mathrm{ha}, 7.881 \mathrm{~kg} / \mathrm{ha}$ en $7.514 \mathrm{~kg} / \mathrm{ha} ; \mathrm{p}=0.012$ ). De VEM-opbrengst was het hoogst voor de teeltmethoden ruitzaai en standaardzaai, gevolgd door drijfmestrijenbemesting (respectievelijk 21.355 $\mathrm{kg} / \mathrm{ha}, 20.908 \mathrm{~kg} / \mathrm{ha}$ en $20.308 \mathrm{~kg} / \mathrm{ha}$; $\mathrm{P}<0.001$ ). In lijn met de $\mathrm{N}$-opbrengst was de $\mathrm{N}$ recovery hoger voor de teeltmethoden ruitzaai en standaardzaai vergeleken met drijfmestrijenbemesting (respectievelijk 62\%, 59\% en 56\%; $\mathrm{P}=0.005$ ).

Het hoge $\mathrm{N}$-niveau met $150 \mathrm{~kg} / \mathrm{ha}$ had een hogere verse opbrengst vergeleken met het lage $\mathrm{N}$-niveau met $100 \mathrm{~kg} / \mathrm{ha}$ (respectievelijk $53.533 \mathrm{~kg} / \mathrm{ha}$ en $51.031 \mathrm{~kg} / \mathrm{ha}(P<0.001$ ), een hogere DS-opbrengst (respectievelijk $21.180 \mathrm{~kg} / \mathrm{ha}$ en $20.500 \mathrm{~kg} / \mathrm{ha} ; \mathrm{P}<0.001$ ) en een hogere $\mathrm{N}$-opbrengst (respectievelijk $230 \mathrm{~kg} / \mathrm{ha}$ en $212 \mathrm{~kg} / \mathrm{ha} ; \mathrm{P}<0.001$ ). De $\mathrm{N}$-recovery was zoals verwacht lager vergeleken met het lage $\mathrm{N}$-niveau (respectievelijk 55\% en 63\%; P<0.001).

Het hoge plantaantal met 110.000 planten/ha had gemiddeld een hogere verse opbrengst vergeleken met het lage plantaantal met 80.000 planten/ha (respectievelijk $53.581 \mathrm{~kg} / \mathrm{ha}$ en $50.983 \mathrm{~kg} / \mathrm{ha}$; $\mathrm{P}<0.001)$ en een hogere DS-opbrengst $(21.360 \mathrm{~kg} / \mathrm{ha}$ en $20.320 \mathrm{~kg} / \mathrm{ha} ; \mathrm{P}<0.001)$, maar geen 
significant hogere $\mathrm{N}$-opbrengst. Dit resulteerde daardoor niet in een hogere $\mathrm{N}$-recovery vergeleken met het lage plantaantal (respectievelijk $60 \%$ en $58 \%$; $P=0.095$ ).

Tabel 7 toont de resultaten voor de gemiddelde gewassamenstelling (2016-2019). Evenals bij de jaaropbrengsten zijn de resultaten per factor weergegeven als gemiddelde over de andere factoren omdat er geen significante interactie-effecten zijn gevonden over de jaren heen tussen enerzijds de teeltmethoden en anderzijds $\mathrm{N}$ niveau, rastype en plantaantallen. Er zijn geen significante verschillen gevonden in de zetmeel-, VEM-, DVE-, OEB-, N- en P-gehalten voor de verschillende teeltmethoden. Het hoge $\mathrm{N}$-niveau (150) had een lager zetmeelgehalte, een hoger $\mathrm{N}$-gehalte en een lager P-gehalte dan het lage N-niveau (100).

De DS- en N-opbrengsten voor de afzonderlijke jaren zijn weergeven in de figuren 9a en 9b. Hieruit blijkt dat de hogere gemiddelde DS-opbrengst van de teeltmethode ruitzaai vooral werd veroorzaakt door de jaren 2018 en 2019. De lagere DS- en N-opbrengsten voor de teeltmethode drijfmestrijenbemesting vergeleken met zowel ruitzaai als standaardzaai waren het meest uitgesproken in 2016. In dat jaar was er tevens een significante interactie tussen teeltmethode en rastype $(P=0.003)$ waarbij de lagere $D S$-opbrengst voor de teeltmethode drijfmestrijenbemesting veroorzaakt werd door het dichte rastype. $\mathrm{Bij}$ het open rastype waren de verschillen tussen de teeltmethoden beperkt. 
Tabel 6 Effecten van verschillende factoren op de jaaropbrengsten (gem. 2016-2019) in kg per ha, tenzij anders vermeld.

\begin{tabular}{|c|c|c|c|c|c|c|c|c|c|}
\hline & & Verse opbrengst & $\begin{array}{l}\text { Drogestof- } \\
\text { gehalte } \\
(\%)\end{array}$ & $\begin{array}{l}\text { Drogestof- } \\
\text { opbrengst }\end{array}$ & $\mathrm{N}$-opbrengst & $\begin{array}{l}\text { Fosfaat- } \\
\text { opbrengst }\end{array}$ & $\begin{array}{l}\text { Zetmeel- } \\
\text { opbrengst }\end{array}$ & VEM-opbrengst & $\begin{array}{c}\text { N-recovery } \\
(\%)\end{array}$ \\
\hline \multirow{4}{*}{ Teeltmethoden } & Standaardzaai & 52.065 & $40.1^{\mathrm{b}}$ & $20.865^{b}$ & $222^{\mathrm{b}}$ & $84^{\mathrm{ab}}$ & $7.881^{b}$ & $20.908^{\mathrm{b}}$ & $59^{b}$ \\
\hline & Ruitzaai & 53.084 & $40.3^{\mathrm{ab}}$ & $21.317^{c}$ & $225^{b}$ & $86^{b}$ & $7.838^{\mathrm{b}}$ & $21.355^{b}$ & $62^{b}$ \\
\hline & Drijfmestrijenbemesting & 51.697 & $39.6^{\mathrm{a}}$ & $20.338^{\mathrm{a}}$ & $216^{a}$ & $82^{a}$ & $7.514^{a}$ & $20.308^{a}$ & $56^{\mathrm{a}}$ \\
\hline & $P$-waarde $(F)$ & 0.139 & 0.049 & $<0.001$ & 0.004 & 0.012 & 0.012 & $<0.001$ & 0.005 \\
\hline \multirow{3}{*}{$\mathrm{N}$-niveaus } & 100 & 51.031 & 40.3 & 20.500 & 212 & 84 & 7.701 & 20.535 & 63 \\
\hline & 150 & 53.533 & 39.7 & 21.180 & 230 & 84 & 7.787 & 21.179 & 55 \\
\hline & P-waarde (F) & $<0.001$ & 0.005 & $<0.001$ & $<0.001$ & 0.799 & 0.420 & 0.004 & $<0.001$ \\
\hline \multirow[t]{3}{*}{ Rastypen } & Dicht & 51.335 & 40.5 & 20.740 & 219 & 85 & 7.972 & 20.571 & 58 \\
\hline & Open & 53.228 & 39.5 & 20.940 & 222 & 83 & 7.517 & 21.143 & 60 \\
\hline & P-waarde (F) & 0.002 & $<0.001$ & 0.267 & 0.208 & 0.012 & $<0.001$ & 0.009 & 0.225 \\
\hline \multirow[t]{3}{*}{ Plantaantal } & 80.000 & 50.983 & 40.0 & 20.320 & 219 & 84 & 7.622 & 20.497 & 58 \\
\hline & 110.000 & 53.581 & 40.0 & 21.360 & 223 & 85 & 7.866 & 21.217 & 60 \\
\hline & $P$-waarde $(F)$ & $<0.001$ & 0.814 & $<0.001$ & 0.136 & 0.396 & 0.024 & 0.001 & 0.095 \\
\hline
\end{tabular}

Tabel 7 Effecten van de verschillende factoren op de samenstelling (gem. 2016-2019) in g per kg drogestof.

\begin{tabular}{|c|c|c|c|c|c|c|c|}
\hline & & Zetmeel & VEM & DVE & OEB & $\mathrm{N}$-gehalte & P-gehalte \\
\hline \multirow[t]{4}{*}{ Teeltmethoden } & Standaardzaai & 376 & 1.001 & 58 & -47 & 10.6 & 1.76 \\
\hline & Ruitzaai & 367 & 1.002 & 59 & -48 & 10.6 & 1.76 \\
\hline & Drijfmestrijenbemesting & 368 & 998 & 58 & -48 & 10.6 & 1.77 \\
\hline & P-waarde $(F)$ & 0.118 & 0.482 & 0.114 & 0.086 & 0.667 & 0.682 \\
\hline \multirow[t]{3}{*}{$\mathrm{N}$-niveaus } & 100 & 374 & 1.001 & 57 & -48 & 10.3 & 1.80 \\
\hline & 150 & 366 & 1.000 & 59 & -47 & 10.9 & 1.73 \\
\hline & $P$-waarde (F) & 0.037 & 0.626 & $<0.001$ & 0.140 & $<0.001$ & $<0.001$ \\
\hline \multirow[t]{3}{*}{ Rastype } & Dicht & 383 & 992 & 56 & -45 & 10.6 & 1.80 \\
\hline & Open & 357 & 1.009 & 60 & -51 & 10.6 & 1.73 \\
\hline & P-waarde (F) & $<0.001$ & $<0.001$ & $<0.001$ & $<0.001$ & 0.980 & $<0.001$ \\
\hline \multirow[t]{3}{*}{ Plantaantal } & 80.000 & 375 & 1.008 & 59 & -47 & 10.8 & 1.80 \\
\hline & 110.000 & 366 & 993 & 57 & -48 & 10.4 & 1.73 \\
\hline & $P$-waarde (F) & 0.024 & $<0.001$ & $<0.001$ & 0.238 & $<0.001$ & $<0.001$ \\
\hline
\end{tabular}




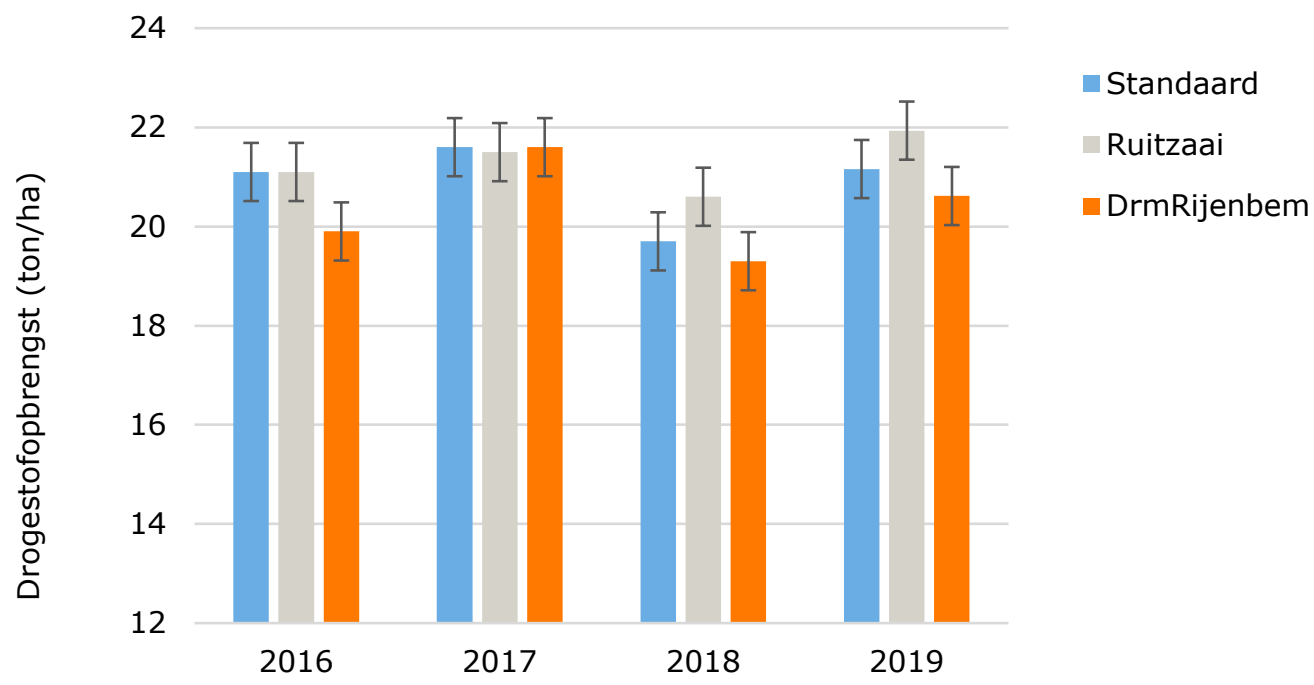

Figuur 9a Drogestofopbrengsten in de afzonderlijke jaren (2016-2019) voor standaardzaai, ruitzaai en drijfmestrijenbemesting.

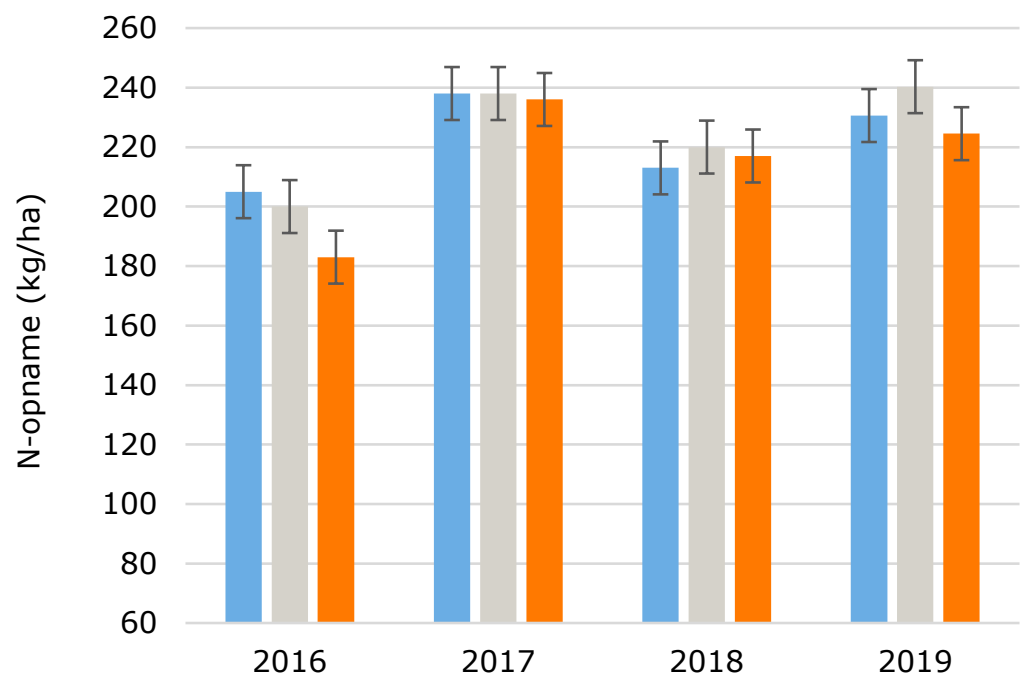

- Standaard

Ruitzaai

DrmRijenbem

Figuur $9 \boldsymbol{b} \quad \mathrm{N}$-opbrengsten in de afzonderlijke jaren (2016-2019) voor standaardzaai, ruitzaai en drijfmestrijenbemesting.

\section{3}

Beworteling

In figuur 10 zijn voor de twee rastypen per teeltmethode de gemiddelde wortelmassa's weergeven, die gemeten zijn op een afstand van 5,20 en $37,5 \mathrm{~cm}$ in de lagen $0-15$ en $15-30 \mathrm{~cm}$.

Bij beide monstermomenten werden er gemiddeld over 3 onderzoeksjaren geen statistisch betrouwbare verschillen in hoeveelheid wortelmassa (DS) gevonden tussen de teeltmethoden (figuur 10). Verschillen die wel werden gevonden waren toe te schrijven aan het (open of dichte) rastype (niet weergegeven). Voor betrouwbare uitspraken over de plaats van de wortelmassa lijkt - bij de relatief geringe opbrengstverschillen waarbij wordt gemeten - een veel grotere dataset nodig om mogelijk aanwezige verschillen aan te tonen. 


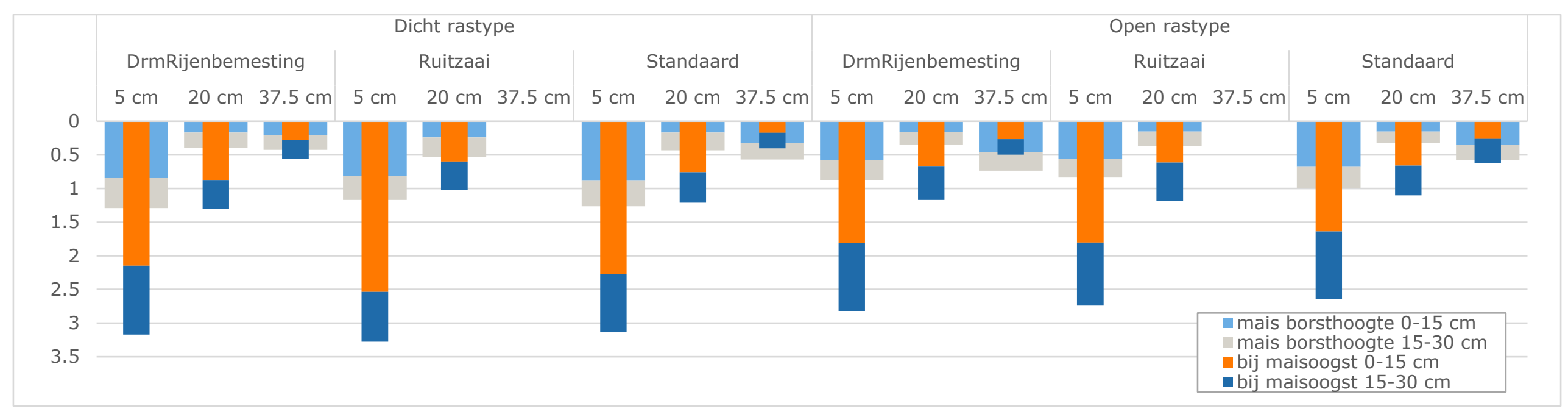

Figuur 10 Gemiddelde (2016-2018) wortelmassa ( $g$ DS per liter grond) per teeltmethode bij twee rastypen, gemeten op 3 afstanden vanaf de maïsrij (5, 20 en 37,5 cm) en 2 monsterdieptes (0-15 en 15-30 cm). 
In figuur $11 \mathrm{a}$ is van de drie teeltmethoden het verloop weergegeven van de indringingsweerstand in de laag 10-35 cm dwars over een veldje van $6 \mathrm{~m}$ breed. Het verloop per teeltmethode van de drie afzonderlijke jaren (2017-2019) vertoonde een grote mate van overeenkomst, daarom is in figuur 11a per teeltmethode het gemiddelde verloop over de drie jaren weergegeven. Bij zowel standaardzaai als bij drijfmestrijenbemesting vertoonde de indringingsweerstand tussen de maisrijen $\mathrm{m} 2$ en $\mathrm{m} 3$ en tussen de maisrijen $\mathrm{m} 4$ en $\mathrm{m} 5$ een duidelijke verhoging ten opzichte van de overige locaties. De bodem was op die plek hoogstwaarschijnlijk wat verdicht door de rijsporen van de trekker tijdens het zaaien. Bij drijfmestrijenbemesting was de piek van indringingsweerstand tussen die rijen nog wat hoger dan bij standaardzaai. Mogelijk was de bodem voor het zaaien gemiddeld nog wat dichter door het injecteren van de mest het de zelfrijdende driewieler, ondanks dat er met woelers werd gewerkt om de bodem weer los te maken. Dit wordt bevestigd door het beeld dat de indringingsweerstand bij de behandeling met drijfmestrijenbemesting tussen en aan de buitenkant van de zaaisporen ook wat hoger is dan bij standaardzaai. Dit beeld werd hoogstwaarschijnlijk veroorzaakt door het voorwiel (tussen de zaaisporen) van de zelfrijdende driewieler en de brede achterbanden. Bij ruitzaai is te zien dat er met een trekker met brede banden met een lage bandenspanning werd gezaaid. Ten opzichte van standaardzaai was op de plek van de zaaisporen de bodem minder verdicht, terwijl het gebied met meer verdichting breder was.

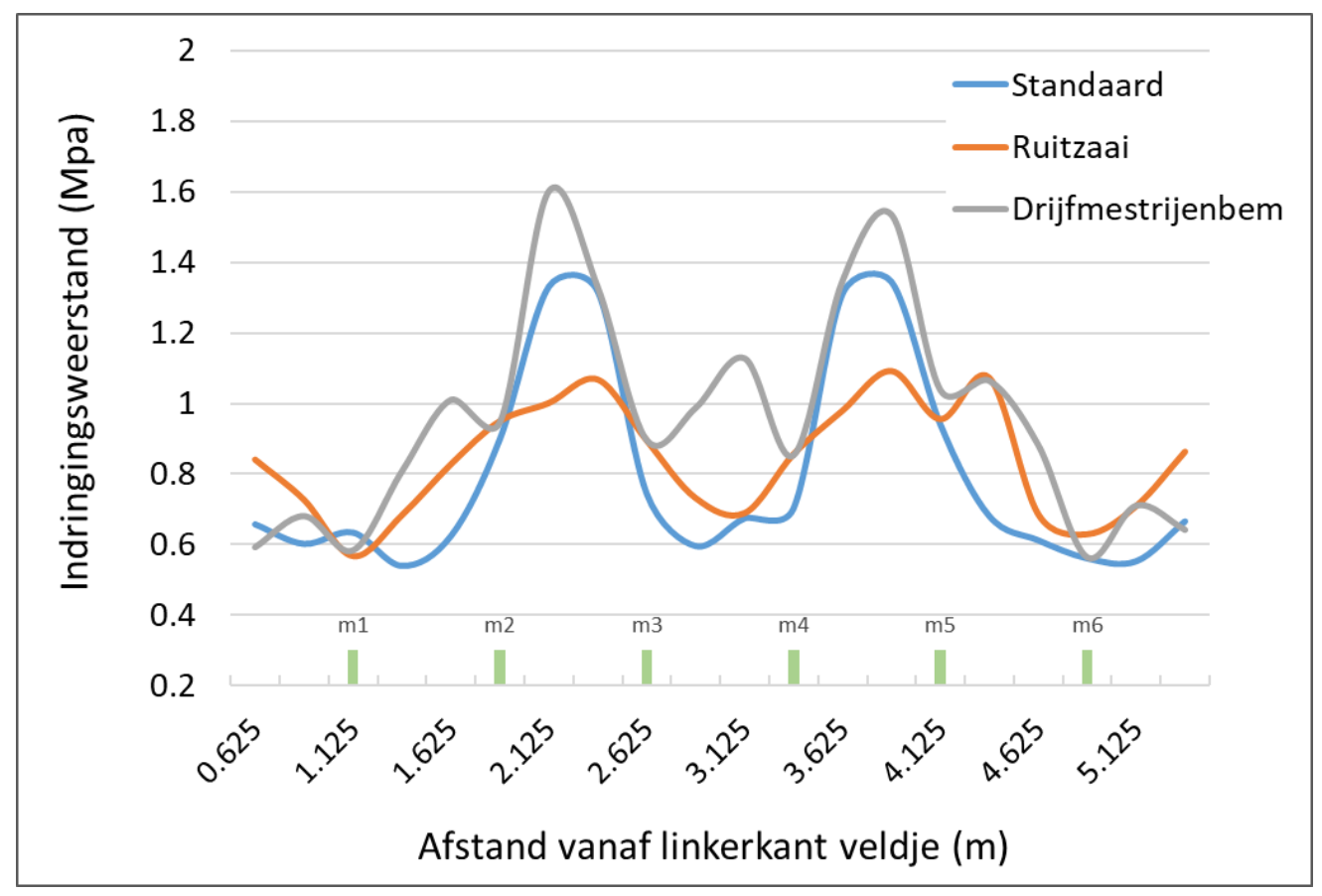

Figuur 11a Verloop van de indringingsweerstand in de laag 10-35 cm dwars over een veldje van $6 \mathrm{~m}$ breed per teeltmethode, gemiddeld over drie jaar (2017-2019).

Uit de punten die de lijnen vormen zoals in figuur 11 a weergegeven, is per teeltmethode een gemiddelde dichtheid berekend. Dit is voor de jaren 2017 t/m 2019 afzonderlijk gedaan. Deze gemiddelde indringingsweerstand per teeltmethode zijn weergegeven in figuur 11b. In de jaren 2017 en 2018 was de dichtheid van de bodem significant hoger voor drijfmestrijenbemesting vergeleken met standaardzaai en ruitzaai. 


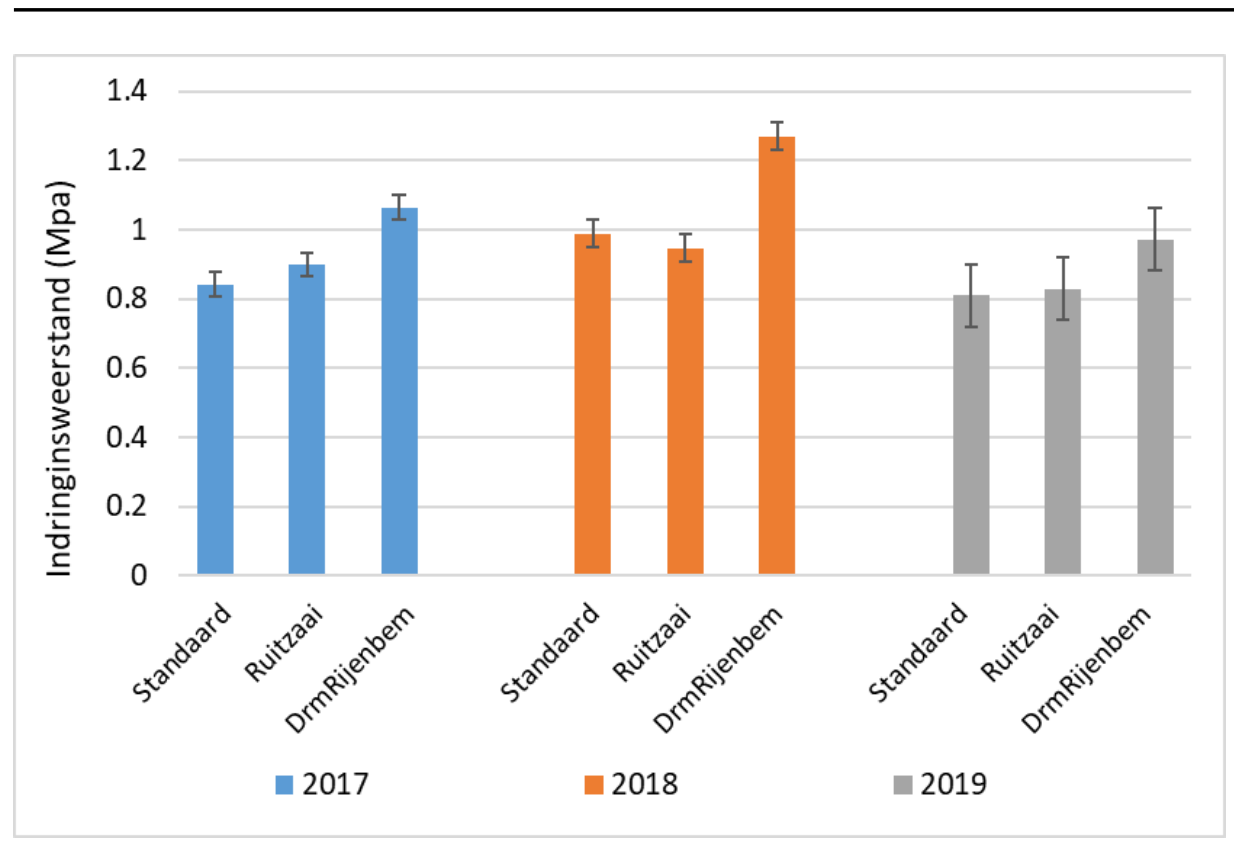

Figuur 11b Gemiddelde indringingsweerstand in de laag 10-35 cm voor de afzonderlijke jaren $2017-2019$ 


\section{Discussie}

Over het algemeen scoort drijfmestrijenbemesting minder goed in vergelijking met standaardzaai of ruitzaai met bouwlandinjectie dan verwacht op basis van bestaande literatuur en experimenten. Schröder et al. (2015) beschrijven veertien bestaande experimenten waarin drijfmestrijenbemesting vergeleken wordt met bouwlandinjectie. In elf van deze veertien experimenten is de vergelijking tussen drijfmestrijenbemesting en bouwlandinjectie gedaan na het ploegen. Hierdoor kan een robuuste vergelijking gemaakt worden tussen de verschillende methodes voor mestplaatsing omdat het effect van rijschade zo wordt uitgeschakeld. In de praktijk wordt, net als in het in dit rapport beschreven experiment, de bouwlandinjectie voor het ploegen gedaan zodat het zware materiaal niet over de hoofdgrondbewerking hoeft te rijden. Bij drijfmestrijenbemesting gebeurt dit echter wel na het ploegen zodat de mest naar de plant gebracht kan worden. Deze interactie met ploegen is in de praktijk dus wel degelijk aanwezig. De overige drie van de veertien experimenten die beschreven staan in Schröder et al. (2015) zijn uitgevoerd op Vredepeel in de jaren 2010, 2011 en 2012. In 2010 is dezelfde systematiek toegepast als in het experiment beschreven in dit rapport. In 2011 en 2012 is gebruik gemaakt van een niet-kerende grondbewerking met woelen of alleen toplaag bewerking waardoor er minder kans op verdichtingseffecten verwacht wordt. In het experiment op Vredepeel in 2010 heeft bouwlandinjectie een hogere DS-opbrengst dan drijfmestrijenbemesting, in lijn met het in dit rapport beschreven experiment. Een mogelijke verklaring hiervoor is dat de interactie met de hoofdgrondbewerking zorgt voor een andere ranking in prestatie van de verschillende teeltmethoden. Op basis van de metingen met de penetrometer konden we zien dat de dichtheid van de bodem in de laag 10-35 cm significant hoger was voor de teeltmethode drijfmestrijenbemesting vergeleken met standaardzaai en ruitzaai in de jaren 2017 en 2018. Deze indicatie vraagt om vervolgonderzoek waarbij in één experiment bouwlandinjectie voor en na het ploegen wordt vergeleken met drijfmestrijenbemesting.

Het verloop van de DS- opbrengst voor de afzonderlijke jaren liet zien dat de hogere gemiddelde opbrengsten van de teeltmethode ruitzaai vooral werden veroorzaakt door de jaren 2018 en 2019. De lagere DS- en N-opbrengsten voor de teeltmethode "drijfmestrijenbemesting" vergeleken met zowel ruitzaai als standaardzaai waren het meest uitgesproken in 2016. Een mogelijke verklaring hiervoor zou kunnen zijn dat het verdichtingseffect over jaren is toegenomen, maar aangezien we in 2016 geen data hebben voor indringingsweerstand kunnen we dit niet toetsen op basis van de data. In 2016 kon de lagere DS-opbrengst voor de teeltmethode "drijfmestrijenbemesting" toegewezen worden aan het met name het dichte rastype. Mogelijk heeft het dichte rastype meer last gehad van het verdichtingseffect bij drijfmestrijenbemesting. In lijn met de eerdere opmerking vragen deze bevindingen om vervolgonderzoek waarbij in één experiment bouwlandinjectie voor en na het ploegen wordt vergeleken met drijfmestrijenbemesting en de verdichting bij deze verschillende teeltmethoden systematisch wordt getoetst.

In figuren $12 \mathrm{a}$ en $12 \mathrm{~b}$ zijn respectievelijk de gemiddelde DS-opbrengsten en $\mathrm{N}$-opnames van objecten met 0 , ca. 100 en ca. 150 kg N-werkzaam weergegeven. In Figuur 12a is te zien dat de DSopbrengsten van de veldjes zonder $\mathrm{N}$-bemesting alle vier de jaren opvallend hoog waren en in latere proefjaren ook nauwelijks lager waren dan in het eerste proefjaar. Ze lagen steeds tussen de 16,5 en 17,5 ton per hectare. In figuur $12 \mathrm{~b}$ is te zien dat ook de $\mathrm{N}$-opbrengsten van de veldjes zonder $\mathrm{N}$ bemesting opvallend hoog waren. In 2016 (eerste jaar) was de $\mathrm{N}$-opbrengst $140 \mathrm{~kg}$ per ha en in de drie daaropvolgende jaren $120 \mathrm{~kg}$ per ha. Blijkbaar was de bodemkwaliteit van het proefperceel beter dan gemiddeld, waardoor de bodem meer stikstof leverde dan gemiddeld. Het hoge N-leverend vermogen heeft er hoogstwaarschijnlijk ook voor gezorgd dat het verschil in drogestofopbrengst en $\mathrm{N}$ opname tussen het hoge en het lage $\mathrm{N}$-niveau (respectievelijk ca. 150 en $100 \mathrm{~kg} \mathrm{~N} / \mathrm{ha}$ ) beperkt was. Gemiddeld over de jaren waren de DS-opbrengst en de N-opname van het hoge N-niveau (gem. 146 kg N-werkz. per ha) respectievelijk maar 700 en $18 \mathrm{~kg}$ per ha hoger dan van het lage $\mathrm{N}$-niveau (gem. $91 \mathrm{~kg} \mathrm{~N}$-werkz. per ha). Op basis van de responsecurve uit Schröder (1998) zouden de ds-opbrengst en $\mathrm{N}$-opname van het lage $\mathrm{N}$-niveau resp. ca. $8 \%$ en $17 \%$ lager uit komen dan die van het hoge $\mathrm{N}$ niveau. Dit komt overeen met een verschil van ca $1200 \mathrm{~kg}$ DS/ha en $38 \mathrm{~kg} \mathrm{~N} / \mathrm{ha}$. 
a)

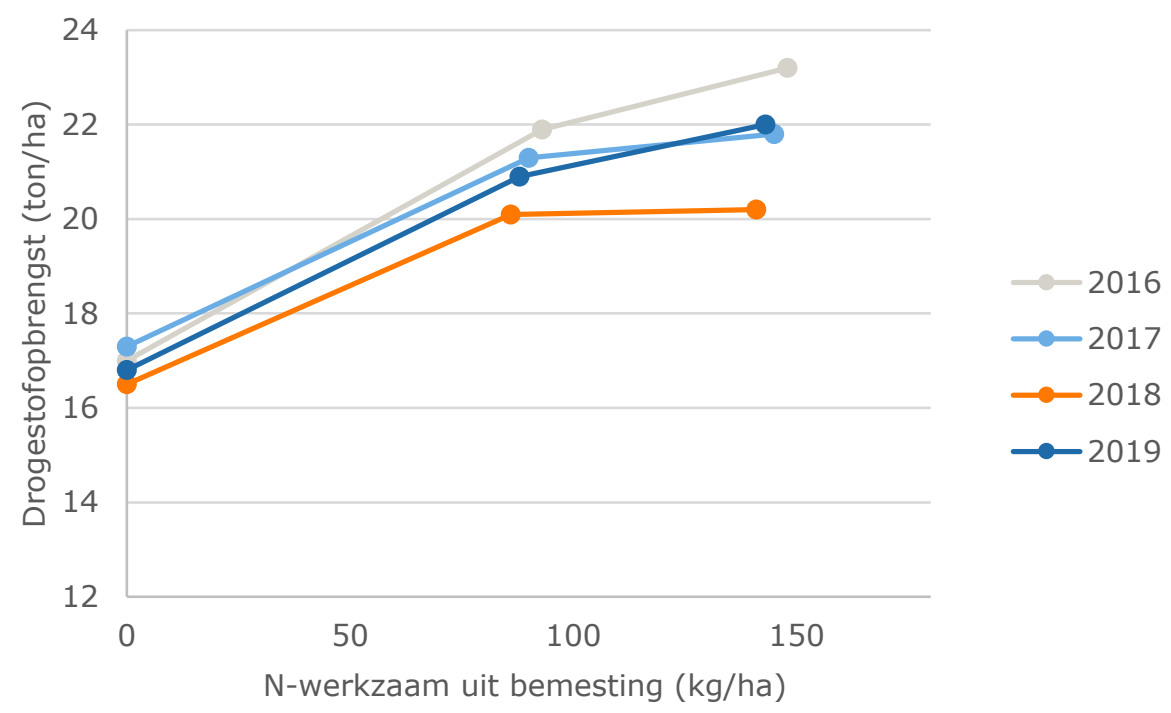

b)

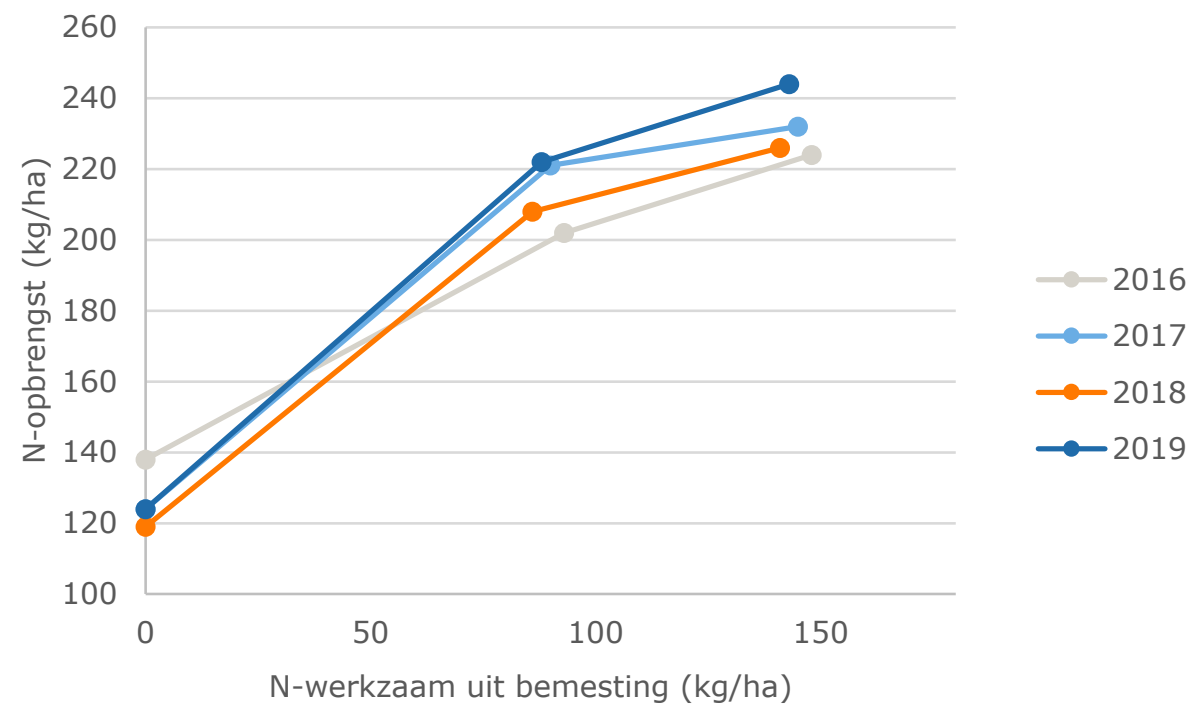

Figuur 12a+b Drogestofopbrengst en N opname (2016-2019) voor verschillende niveaus van werkzame $N$ uit bemesting.

In het $6^{e}$ actieprogramma betreffende de nitraatrichtlijn is opgenomen dat per 1 januari 2021 de toepassing van precisiebemesting (rijenbemesting) van toegediende kunstmest en verpompbare dierlijke mest in rijen geplante maïs op alle zand- en lössgronden verplicht wordt, met uitzondering van percelen waarvan een substantieel deel van het perceel grondwatertrap I tot en met IV heeft. Deze maatregel is vooral gericht op minder uitspoeling van stikstof in de bodem. Via modelberekeningen is nagegaan hoe de nitraatconcentratie reageert als mest bij maïs niet volvelds geïnjecteerd wordt maar overal als rijenbemesting. Op basis van onderzoek in het verleden met drijfmestrijenbemesting is de relatieve benutting van mest- $\mathrm{N}$ die als rijenbemesting gegeven wordt gesteld op een factor 1,25 . Met deze betere benutting als uitgangspunt zijn de effecten op nitraatconcentraties van het bovenste grondwater berekend met de modellen WOD en WOG (CDM, 2017). De uitkomst was dat rijenbemesting de berekende nitraatconcentratie van het grondwater op perceelsniveau verlaagt met circa $4 \mathrm{mg}$ nitraat- $\mathrm{N}$ per liter. In onderhavig onderzoek werd geen betere $\mathrm{N}$-benutting gevonden van de mest die als rijenbemesting werd gegeven. 
De N-opname van de behandelingen met drijfmestrijenbemesting was zelfs $6 \mathrm{~kg}$ per ha lager dan van de behandelingen met standaardzaai. Op basis van bovenstaande rekenmethode zou hiermee de nitraatconcentratie van het grondwater op perceelsniveau circa $1 \mathrm{mg}$ nitraat-N per liter hoger worden. Het verschil in $\mathrm{N}$-opname tussen ruitzaai en standaardzaai was niet significant.

In het Handboek Bodem en Bemesting (www.handboekbodemenbemesting. $\mathrm{nl}$ ) wordt aangegeven dat een veelgebruikte vuistregel is dat een indringingsweerstand van $3 \mathrm{MPa}$ een grenswaarde is voor de wortelgroei. Bij hogere waarden kunnen wortels niet of nauwelijks doordringen in de bodem. De remming van de wortelgroei begint echter al bij een indringings-weerstand van 1,5 MPa. In de figuren $11 \mathrm{a}$ en $11 \mathrm{~b}$ is te zien dat de gemiddelde indringingsweerstand van de bodem van de behandelingen met drijfmestrijenbemesting hoger was dan van de behandelingen met standaardzaai en ruitzaai. Alleen de hoogste indringingsweerstanden in de zaaisporen van de behandelingen drijfmestrijenbemesting en standaardzaai liggen rond de 1,5 MPa, waarbij die van de behandeling met drijfmestrijenbemesting tendeerden tot wat hoger. De overige waarden liggen allemaal (ruim) onder de 1,5 MPa. Op basis hiervan zou de conclusie kunnen zijn dat de wat hogere gemiddelde indringingsweerstand van de behandelingen met drijfmestrijenbemesting ten opzichte van de beide andere teeltmethoden nauwelijks tot geen remming heeft veroorzaakt op de wortelgroei. Hierbij dient bedacht te worden dat het om gemiddelde waarden gaat. De waarden kunnen lokaal binnen een enkel veldje hoger liggen en daarmee lokaal tot wat wortelgroeiremming hebben geleid. Het verschil in opbrengst tussen de teeltmethoden drijfmestrijenbemesting en standaardzaai was in 2016 het grootst. In dat jaar zijn echter geen indringingsweerstandmetingen uitgevoerd. De lagere opbrengst van de teeltmethode drijfmestrijenbemesting in dat jaar was aanleiding om in de volgende jaren wel metingen uit te voeren. 


\section{$5 \quad$ Conclusies}

In de periode $2016 \mathrm{t} / \mathrm{m} 2019$ is een vierjarige veldproef uitgevoerd naar het effect van een betere plantverdeling in de vorm van ruitzaai op de stikstofbenutting ten opzichte van de standaard rijafstand van $75 \mathrm{~cm}$ met bouwlandinjectie en met drijfmestrijenbemesting. Tevens zijn de interacties van de drie teeltmethoden met twee $\mathrm{N}$-bemestingsniveaus, twee plantaantallen en twee rastypen onderzocht. De verschillende proefbehandelingen zijn elk jaar exact op dezelfde locatie aangelegd om eventuele meerjarige effecten mee te nemen. De weersomstandigheden in de vier jaren varieerden van een jaar met relatief veel piekneerslagen (2016) tot twee droge jaren met perioden met hoge temperaturen (2018 en 2019). Uit de onderzoeksresultaten kunnen de volgende conclusies worden samengevat:

- Gemiddeld over de vier proefjaren waren er geen significante interactie effecten van teeltmethode met N-niveau, rastype en plantaantal wat betreft opbrengsten aan drogestof, VEM, en zetmeel en $\mathrm{N}$-opname en $\mathrm{N}$-recovery.

- Ten opzicht van de standaard teeltmethode waren de opbrengsten aan drogestof, VEM en zetmeel van de teeltmethode met drijfmestrijenbemesting in de vier proefjaren gelijk of lager en gemiddeld resp. circa 530, 600 en $370 \mathrm{~kg} / \mathrm{ha}$ lager.

- De opbrengst aan drogestof van teeltmethode met ruitzaai was in de vier proefjaren gelijk of hoger dan van de standaard teeltmethode en gemiddeld circa $450 \mathrm{~kg} / \mathrm{ha}$ hoger.

- De ontwikkeling van de mais van de behandeling met drijfmestrijenbemesting bleef in het 7-8 bladstadium wat achter bij de beide andere teeltmethoden. Gemiddeld was de DS-opbrengst in dat stadium $12-13 \%$ lager.

- $\quad$ Ten opzicht van de standaard teeltmethode waren de N-opname en N-recovery van de teeltmethode met drijfmestrijenbemesting gedurende de vier proefjaren gelijk of lager en gemiddeld resp. $7 \mathrm{~kg} / \mathrm{ha}$ en $3 \%$ lager.

- $\quad$ De N-opname en N-recovery van de teeltmethode met ruitzaai waren gemiddeld over vier proefjaren praktisch gelijk aan die van de standaard teeltmethode.

- Tussen de drie teeltmethoden zaten geen significante verschillen in voederwaardesamenstelling.

- Ten opzichte van bouwlandinjectie voor het ploegen had rijeninjectie na het ploegen een licht verhogend effect op de indringingsweerstand van de bodem, ondanks dat er bij rijeninjectie met woelers werd gewerkt om de sporen los te trekken.

- $\quad$ Er werd geen verschil in wortelmassa en wortelpatroon gevonden tussen de drie teeltmethoden in het 7-8 bladstadium en bij de oogst.

In dit onderzoek gaf een meer evenredige plantverdeling in de vorm van ruitzaai een licht hogers dsopbrengst dan een standaard rijafstand van $75 \mathrm{~cm}$, maar dit leidde niet tot een significant hogere stikstofbenutting. De ds-opbrengst en stikstofbenutting van drijfmestrijenbemesting waren in tegenstelling tot eerder uitgevoerd onderzoek wat lager vergeleken met standaard bouwlandinjectie. In de praktijk wordt bouwlandinjectie vaak uitgevoerd voor het ploegen terwijl in eerdere onderzoeken zowel bouwlandinjectie als drijfmestrijeninjectie veelal na het ploegen zijn uitgevoerd ten dienste van een robuuste vergelijking tussen deze twee methoden voor mestaanwending. Indicaties uit onderhavig onderzoek laten zien dat het mogelijke verdichtingseffect bij drijfmestrijenbemesting in de praktijk een rol kan spelen bij de verschillen van de resultaten vergeleken met eerder uitgevoerd onderzoek. Vervolgonderzoek is nodig waarbij in één experiment bouwlandinjectie voor en na het ploegen wordt vergeleken met drijfmestrijenbemesting en de verdichting bij deze verschillende teeltmethoden systematisch wordt getoetst. De resultaten in dit onderzoek geven inzicht in het meerjarig effect van een meer evenredige plantverdeling op de benutting van stikstof ten opzichte van de standaard rijafstand van $75 \mathrm{~cm}$ met en zonder drijfmestrijenbemesting waarbij positieve resultaten zijn gevonden die erop wijzen dat de teeltmethoden ruitzaai en standaardzaai zeker niet minder en zelfs iets beter presteren dan drijfmestrijenbemesting als het gaat om DS-opbrengst en N-recovery. 


\section{Literatuur}

Commissie Bemesting Akkerbouw/Vollegrondsgroententeelt, 2019. Handboek Bodem en Bemesting, www.handboekbodemenbemesting.nl.

Commissie Deskundigen Meststoffenwet, 2017. CDM-advies 'Effecten van rijenbemesting bij maisgewassen op nitraatconcentratie van grondwater in het zuidelijk zand- en lösgebied.

Demmel, M., O. Hahnenkamm \& M. Peterreins, 2002. Höhere Erträge durg bessere Standraumverteilung? Versuchsergebnisse zur Gleichstandsaat von Mais. In: Mais 1/2002, p. 4-7.

RVO, 2019. Mestbeleid 2019-2021 Tabellen; Tabel 5 Forfaitaire stikstof- en fosfaatgehalten in dierlijke mest. Bekeken op 17 Dec. 2019. http://www.rvo.nl/onderwerpen/agrarisch-ondernemen/mestengrond/mest/tabellen-en-publicaties/tabellen-en-normen.

Schans, D.A. van der, W. van Dijk \& O. Dolstra,1995. Invloed van plantverdeling, zaaitijdstip en koudetolerantie op de stikstofbenutting door maïs tijdens de jeugdgroei. Verslag nr. 191. Proefstation voor de Akkerbouw en de Groenteteelt in de Vollegrond, Lelystad.

Schröder, J.J., 1998. Towards improved nitrogen management in silage maize production on sandy soils. Wageningen, proefschrift Wageningen Universiteit.

Schröder, J.J., G.D. Vermeulen, J.R. van der Schoot, W. van Dijk, J.F.M. Huijsmans, G.J.H.M. Meuffels, D.A. van der Schans, 2015. Maize yields benefit from injected manure positioned in bands. Europ. J. Agronomy 64, p 29-36.

Van Dijk, W, H. v. Schooten, M. v. Walbeek en S. Postma, 1995. Deltazaai beïnvloedt opbrengst en kwaliteit snijmais nauwelijks. Praktijkonderzoek 95-2. Praktijkonderzoek Veehouderij, Lelystad,

Van der Schoot, J.R. en W. van Dijk, 2001. Rijenbemesting met dierlijke mest in maïs maakt kunstmest overbodig. PPO-bulletin Akkerbouw 2001-2,p. 13-17.

Van der Werf, H.M.G., en H. Hoek,1988. Bijzaaien en overzaaien van snijmaïs. Verslag nr. 78. Proefstation voor de Akkerbouw en de Groenteteelt in de Vollegrond, Lelystad.

Vermeulen, Bert, Jan Huijsmans, Gerard Meuffels en David van der Schans. 2012. Precisieplaatsing van drijfmest in maïs- Effecten van precisieplaatsing en grondbewerking. Rapport 451.

Wageningen UR Plant Research International. 


\section{Bijlage 1 Resultaten per jaar}

\section{6}

Gemiddelde jaaropbrengsten van de verschillende factoren in $\mathrm{kg}$ per ha, tenzij anders vermeld.

\begin{tabular}{|c|c|c|c|c|c|c|c|c|c|}
\hline & & Verse opbrengst & $\begin{array}{l}\text { Drogestof- } \\
\text { gehalte } \\
(\%)\end{array}$ & $\begin{array}{l}\text { Drogestof- } \\
\text { opbrengst }\end{array}$ & $\mathrm{N}$-opbrengst & $\begin{array}{l}\text { Fosfaat- } \\
\text { opbrengst }\end{array}$ & $\begin{array}{l}\text { Zetmeel- } \\
\text { opbrengst }\end{array}$ & VEM-opbrengst & $\begin{array}{c}\text { N-recovery } \\
(\%)\end{array}$ \\
\hline \multirow[t]{3}{*}{ Teeltmethoden } & Ruitzaai & 50641 & 41.7 & 21250 & 202 & 96 & 7883 & 21245 & 39 \\
\hline & Standaardzaai & 50120 & 42.1 & 21054 & 205 & 94 & 8249 & 21145 & 41 \\
\hline & Drijfmestrijenbemesting & 45758 & 43.2 & 19872 & 185 & 93 & 8070 & 20062 & 28 \\
\hline \multirow[t]{2}{*}{$\mathrm{N}$-niveaus } & 100 & 47243 & 42.7 & 20208 & 188 & 94 & 7834 & 20251 & 36 \\
\hline & 150 & 50437 & 42.0 & 21242 & 207 & 94 & 8301 & 21383 & 36 \\
\hline \multirow[t]{2}{*}{ Rastypen } & Dicht & 50386 & 42.4 & 21396 & 206 & 101 & 8709 & 21356 & 41 \\
\hline & Open & 47294 & 42.3 & 20054 & 189 & 88 & 7426 & 20279 & 30 \\
\hline \multirow[t]{2}{*}{ Plantaantal } & 80.000 & 47128 & 41.9 & 19822 & 194 & 92 & 7699 & 20061 & 34 \\
\hline & 110.000 & 50552 & 42.7 & 21628 & 201 & 97 & 8436 & 21573 & 38 \\
\hline
\end{tabular}

Gemiddelde samenstelling van de verschillende factoren in $\mathrm{g}$ per $\mathrm{kg}$ drogestof.

\begin{tabular}{|c|c|c|c|c|c|c|c|}
\hline & & Zetmeel & VEM & DVE & OEB & $\mathrm{N}$-gehalte & P-gehalte \\
\hline \multirow[t]{3}{*}{ Teeltmethoden } & Ruitzaai & 370 & 1000 & 56 & -52 & 9.5 & 1.98 \\
\hline & Standaardzaai & 390 & 1004 & 55 & -48 & 9.7 & 1.94 \\
\hline & Drijfmestrijenbemesting & 406 & 1009 & 53 & -48 & 9.3 & 2.04 \\
\hline \multirow[t]{2}{*}{$\mathrm{N}$-niveaus } & 100 & 387 & 1002 & 54 & -50 & 9.3 & 2.04 \\
\hline & 150 & 390 & 1007 & 55 & -49 & 9.7 & 1.94 \\
\hline \multirow[t]{2}{*}{ Rastype } & Dicht & 407 & 998 & 52 & -45 & 9.6 & 2.07 \\
\hline & Open & 370 & 1011 & 57 & -53 & 9.4 & 1.91 \\
\hline \multirow[t]{2}{*}{ Plantaantal } & 80.000 & 388 & 1012 & 56 & -49 & 9.6 & 2.02 \\
\hline & 110.000 & 389 & 997 & 53 & -49 & 9.4 & 1.96 \\
\hline
\end{tabular}


2017

Gemiddelde jaaropbrengsten van de verschillende factoren in $\mathrm{kg}$ per ha, tenzij anders vermeld.

\begin{tabular}{|c|c|c|c|c|c|c|c|c|c|}
\hline & & Verse opbrengst & $\begin{array}{c}\text { Drogestof- } \\
\text { gehalte } \\
(\%)\end{array}$ & $\begin{array}{l}\text { Drogestof- } \\
\text { opbrengst }\end{array}$ & $\mathrm{N}$-opbrengst & $\begin{array}{l}\text { Fosfaat- } \\
\text { opbrengst }\end{array}$ & $\begin{array}{l}\text { Zetmeel- } \\
\text { opbrengst }\end{array}$ & VEM-opbrengst & $\begin{array}{c}\text { N-recovery } \\
(\%)\end{array}$ \\
\hline \multirow[t]{3}{*}{ Teeltmethoden } & Ruitzaai & 49079 & 43.5 & 21458 & 238 & 82 & 9001 & 21914 & 75 \\
\hline & Standaardzaai & 49876 & 43.4 & 21559 & 238 & 83 & 9178 & 21861 & 68 \\
\hline & Drijfmestrijenbemesting & 50376 & 42.9 & 21560 & 236 & 81 & 8961 & 21701 & 67 \\
\hline \multirow[t]{2}{*}{$\mathrm{N}$-niveaus } & 100 & 48811 & 43.7 & 21319 & 231 & 84 & 9148 & 21694 & 78 \\
\hline & 150 & 50743 & 42.9 & 21733 & 244 & 80 & 8946 & 21956 & 62 \\
\hline \multirow[t]{2}{*}{ Rastypen } & Dicht & 46857 & 44.5 & 20883 & 225 & 78 & 8989 & 20735 & 62 \\
\hline & Open & 52696 & 42.0 & 22169 & 250 & 86 & 9104 & 22915 & 78 \\
\hline \multirow[t]{2}{*}{ Plantaantal } & 80.000 & 49252 & 42.6 & 20937 & 237 & 82 & 8685 & 21403 & 69 \\
\hline & 110.000 & 50301 & 44.0 & 22115 & 238 & 82 & 9408 & 22248 & 70 \\
\hline
\end{tabular}

Gemiddelde samenstelling van de verschillende factoren in $\mathrm{g}$ per $\mathrm{kg}$ drogestof.

\begin{tabular}{|c|c|c|c|c|c|c|c|}
\hline & & Zetmeel & VEM & DVE & OEB & $\mathrm{N}$-gehalte & P-gehalte \\
\hline \multirow[t]{3}{*}{ Teeltmethoden } & Ruitzaai & 420 & 1020 & 57 & -41 & 11.1 & 1.66 \\
\hline & Standaardzaai & 426 & 1012 & 55 & -39 & 11.0 & 1.68 \\
\hline & Drijfmestrijenbemesting & 416 & 1005 & 55 & -41 & 11.0 & 1.65 \\
\hline \multirow[t]{2}{*}{$\mathrm{N}$-niveaus } & 100 & 429 & 1016 & 55 & -40 & 10.8 & 1.71 \\
\hline & 150 & 412 & 1009 & 57 & -41 & 11.2 & 1.61 \\
\hline \multirow[t]{2}{*}{ Rastype } & Dicht & 431 & 992 & 52 & -38 & 9.6 & 1.64 \\
\hline & Open & 410 & 1033 & 59 & -43 & 9.4 & 1.69 \\
\hline \multirow[t]{2}{*}{ Plantaantal } & 80.000 & 415 & 1021 & 58 & -41 & 9.6 & 1.71 \\
\hline & 110.000 & 426 & 1005 & 54 & -40 & 9.4 & 1.62 \\
\hline
\end{tabular}




\section{8}

Gemiddelde jaaropbrengsten van de verschillende factoren in $\mathrm{kg}$ per ha, tenzij anders vermeld.

\begin{tabular}{|c|c|c|c|c|c|c|c|c|c|}
\hline 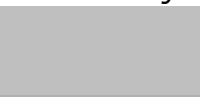 & & Verse opbrengst & $\begin{array}{l}\text { Drogestof- } \\
\text { gehalte } \\
(\%)\end{array}$ & $\begin{array}{l}\text { Drogestof- } \\
\text { opbrengst }\end{array}$ & $\mathrm{N}$-opbrengst & $\begin{array}{l}\text { Fosfaat- } \\
\text { opbrengst }\end{array}$ & $\begin{array}{l}\text { Zetmeel- } \\
\text { opbrengst }\end{array}$ & VEM-opbrengst & $\begin{array}{c}\text { N-recovery } \\
(\%)\end{array}$ \\
\hline \multirow[t]{3}{*}{ Teeltmethoden } & Ruitzaai & 53815 & 38.0 & 20625 & 220 & 89 & 7255 & 20878 & 67 \\
\hline & Standaardzaai & 52605 & 37.5 & 19686 & 213 & 85 & 6883 & 19946 & 58 \\
\hline & Drijfmestrijenbemesting & 55269 & 35.0 & 19308 & 217 & 82 & 6273 & 19412 & 61 \\
\hline \multirow[t]{2}{*}{$\mathrm{N}$-niveaus } & 100 & 52612 & 37.2 & 19574 & 205 & 85 & 6785 & 19794 & 65 \\
\hline & 150 & 55181 & 36.5 & 20172 & 228 & 86 & 6823 & 20364 & 58 \\
\hline \multirow[t]{2}{*}{ Rastypen } & Dicht & 53954 & 36.5 & 19725 & 217 & 86 & 6709 & 19802 & 62 \\
\hline & Open & 53839 & 37.1 & 20021 & 217 & 85 & 6899 & 20355 & 62 \\
\hline \multirow[t]{2}{*}{ Plantaantal } & 80.000 & 51737 & 37.7 & 19542 & 214 & 86 & 6870 & 19767 & 60 \\
\hline & 110.000 & 56055 & 35.9 & 20204 & 219 & 85 & 6738 & 20391 & 63 \\
\hline
\end{tabular}

Gemiddelde samenstelling van de verschillende factoren in $\mathrm{g}$ per $\mathrm{kg}$ drogestof.

\begin{tabular}{|c|c|c|c|c|c|c|c|}
\hline & & Zetmeel & VEM & DVE & OEB & $\mathrm{N}$-gehalte & P-gehalte \\
\hline \multirow[t]{3}{*}{ Teeltmethoden } & Ruitzaai & 350 & 1012 & 62 & -51 & 10.7 & 1.87 \\
\hline & Standaardzaai & 347 & 1012 & 62 & -51 & 10.9 & 1.87 \\
\hline & Drijfmestrijenbemesting & 324 & 1005 & 64 & -52 & 11.3 & 1.86 \\
\hline \multirow[t]{2}{*}{$\mathrm{N}$-niveaus } & 100 & 344 & 1010 & 62 & -52 & 10.5 & 1.89 \\
\hline & 150 & 336 & 1009 & 64 & -51 & 11.4 & 1.84 \\
\hline \multirow[t]{2}{*}{ Rastype } & Dicht & 338 & 1003 & 62 & -51 & 9.6 & 1.89 \\
\hline & Open & 342 & 1016 & 63 & -52 & 9.4 & 1.84 \\
\hline \multirow[t]{2}{*}{ Plantaantal } & 80.000 & 351 & 1011 & 62 & -50 & 9.6 & 1.91 \\
\hline & 110.000 & 330 & 1008 & 63 & -53 & 9.4 & 1.82 \\
\hline
\end{tabular}




\section{9}

Gemiddelde jaaropbrengsten van de verschillende factoren in $\mathrm{kg}$ per ha, tenzij anders vermeld.

\begin{tabular}{|c|c|c|c|c|c|c|c|c|c|}
\hline & & Verse opbrengst & $\begin{array}{l}\text { Drogestof- } \\
\text { gehalte } \\
(\%)\end{array}$ & $\begin{array}{l}\text { Drogestof- } \\
\text { opbrengst }\end{array}$ & $\mathrm{N}$-opbrengst & $\begin{array}{l}\text { Fosfaat- } \\
\text { opbrengst }\end{array}$ & $\begin{array}{l}\text { Zetmeel- } \\
\text { opbrengst }\end{array}$ & VEM-opbrengst & $\begin{array}{c}\text { N-recovery } \\
(\%)\end{array}$ \\
\hline \multirow[t]{3}{*}{ Teeltmethoden } & Ruitzaai & 58801 & 37.1 & 21934 & 240 & 77 & 7211 & 21384 & 77 \\
\hline & Standaardzaai & 55658 & 38.1 & 21159 & 231 & 75 & 7214 & 20681 & 67 \\
\hline & Drijfmestrijenbemesting & 55384 & 37.4 & 20615 & 225 & 73 & 6754 & 20056 & 63 \\
\hline \multirow[t]{2}{*}{$\mathrm{N}$-niveaus } & 100 & 55459 & 37.7 & 20899 & 223 & 74 & 7039 & 20401 & 75 \\
\hline & 150 & 57770 & 37.3 & 21573 & 241 & 76 & 7080 & 21013 & 63 \\
\hline \multirow[t]{2}{*}{ Rastypen } & Dicht & 54144 & 38.7 & 20957 & 230 & 76 & 7482 & 20392 & 68 \\
\hline & Open & 59085 & 36.4 & 21514 & 234 & 74 & 6637 & 21022 & 70 \\
\hline \multirow[t]{2}{*}{ Plantaantal } & 80.000 & 55813 & 37.6 & 20977 & 231 & 76 & 7236 & 20757 & 69 \\
\hline & 110.000 & 57416 & 37.4 & 21494 & 233 & 74 & 6883 & 20658 & 70 \\
\hline
\end{tabular}

Gemiddelde samenstelling van de verschillende factoren in $\mathrm{g}$ per $\mathrm{kg}$ drogestof.

\begin{tabular}{|c|c|c|c|c|c|c|c|}
\hline & & Zetmeel & VEM & DVE & OEB & $\mathrm{N}$-gehalte & P-gehalte \\
\hline \multirow[t]{3}{*}{ Teeltmethoden } & Ruitzaai & 329 & 975 & 60 & -50 & 11.0 & 1.53 \\
\hline & Standaardzaai & 341 & 977 & 59 & -49 & 10.9 & 1.55 \\
\hline & Drijfmestrijenbemesting & 327 & 972 & 60 & -50 & 10.9 & 1.54 \\
\hline \multirow[t]{2}{*}{$\mathrm{N}$-niveaus } & 100 & 336 & 976 & 59 & -50 & 10.6 & 1.54 \\
\hline & 150 & 328 & 974 & 60 & -49 & 11.2 & 1.54 \\
\hline \multirow[t]{2}{*}{ Rastype } & Dicht & 357 & 973 & 58 & -46 & 9.6 & 1.59 \\
\hline & Open & 308 & 976 & 62 & -53 & 9.4 & 1.49 \\
\hline \multirow[t]{2}{*}{ Plantaantal } & 80.000 & 345 & 989 & 60 & -49 & 9.6 & 1.57 \\
\hline & 110.000 & 320 & 960 & 59 & -50 & 9.4 & 1.51 \\
\hline
\end{tabular}



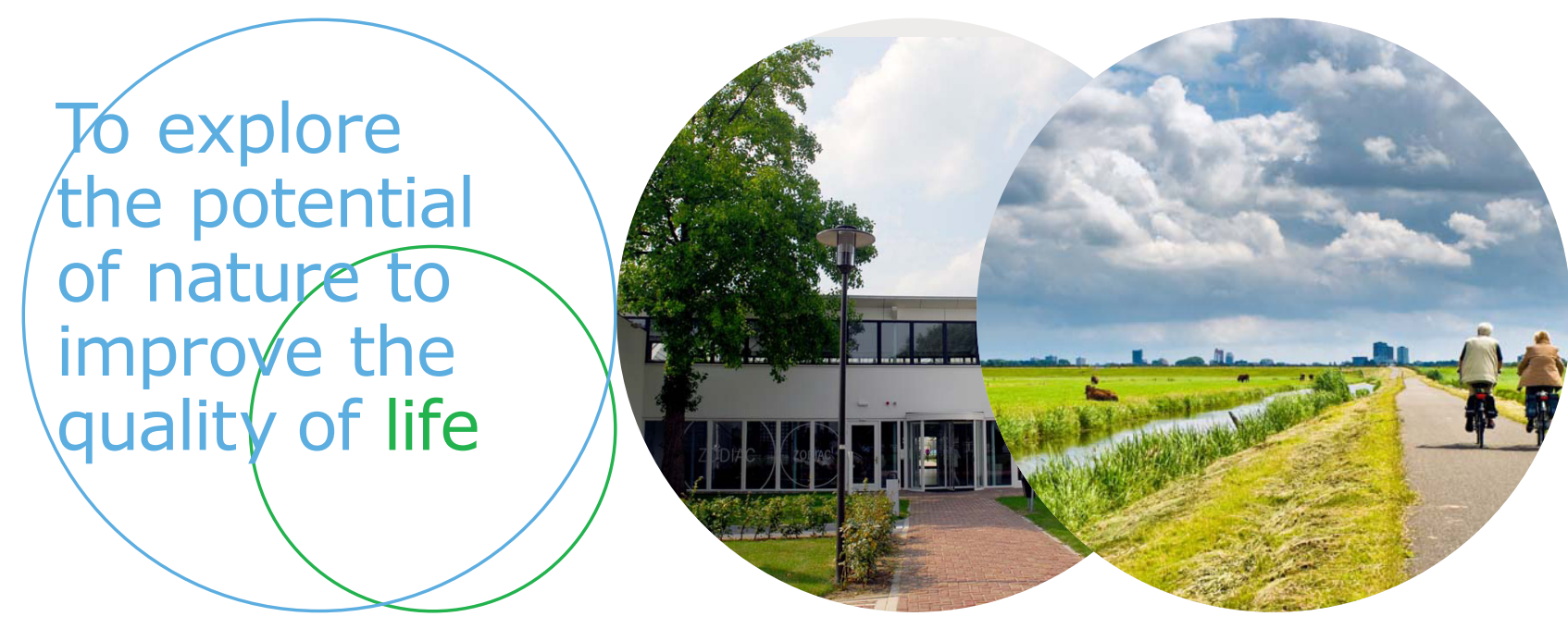

Wageningen Livestock Research Postbus 338

Wageningen Livestock Research ontwikkelt kennis voor een zorgvuldige en $6700 \mathrm{AH}$ Wageningen

T 0317483953

renderende veehouderij, vertaalt deze naar praktijkgerichte oplossingen en innovaties, en zorgt voor doorstroming van deze kennis. Onze wetenschappelijke E info.livestockresearch@wur.nl www.wur.nl/ livestock-research kennis op het gebied van veehouderijsystemen en van voeding, genetica, welzijn en milieu-impact van landbouwhuisdieren integreren we, samen met onze klanten, tot veehouderijconcepten voor de 21 e eeuw.

De missie van Wageningen University \& Research is 'To explore the potential of nature to improve the quality of life'. Binnen Wageningen University \& Research bundelen 9 gespecialiseerde onderzoeksinstituten van Stichting Wageningen Research en Wageningen University hun krachten om bij te dragen aan de oplossing van belangrijke vragen in het domein van gezonde voeding en leefomgeving. Met ongeveer 30 vestigingen, 6.500 medewerkers en 10.000 studenten behoort Wageningen University \& Research wereldwijd tot de aansprekende kennisinstellingen binnen haar domein. De integrale benadering van de vraagstukken en de samenwerking tussen verschillende disciplines vormen het hart van de unieke Wageningen aanpak. 